\title{
The Endometriotic Tumor Microenvironment in Ovarian Cancer
}

\author{
Jillian R. Hufgard Wendel, Xiyin Wang and Shannon M. Hawkins * \\ Department of Obstetrics and Gynecology, Indiana University School of Medicine, Indianapolis, IN 46202, USA; \\ jhufgard@iu.edu (J.R.H.W.); xw49@iu.edu (X.W.) \\ * Correspondence: shhawkin@iu.edu; Tel.: +1-317-274-8225
}

Received: 29 June 2018; Accepted: 2 August 2018; Published: 7 August 2018

\begin{abstract}
Women with endometriosis are at increased risk of developing ovarian cancer, specifically ovarian endometrioid, low-grade serous, and clear-cell adenocarcinoma. An important clinical caveat to the association of endometriosis with ovarian cancer is the improved prognosis for women with endometriosis at time of ovarian cancer staging. Whether endometriosis-associated ovarian cancers develop from the molecular transformation of endometriosis or develop because of the endometriotic tumor microenvironment remain unknown. Additionally, how the presence of endometriosis improves prognosis is also undefined, but likely relies on the endometriotic microenvironment. The unique tumor microenvironment of endometriosis is composed of epithelial, stromal, and immune cells, which adapt to survive in hypoxic conditions with high levels of iron, estrogen, and inflammatory cytokines and chemokines. Understanding the unique molecular features of the endometriotic tumor microenvironment may lead to impactful precision therapies and/or modalities for prevention. A challenge to this important study is the rarity of well-characterized clinical samples and the limited model systems. In this review, we will describe the unique molecular features of endometriosis-associated ovarian cancers, the endometriotic tumor microenvironment, and available model systems for endometriosis-associated ovarian cancers. Continued research on these unique ovarian cancers may lead to improved prevention and treatment options.
\end{abstract}

Keywords: ovarian cancer; endometriosis; tumor microenvironment; miRNA molecules; genes; hypoxia; inflammation; model systems

\section{Introduction}

Endometriosis is a debilitating disease that is estimated to affect up to 5 million U.S. women and girls. Endometriosis results in considerable morbidity, including pelvic pain, multiple operations, infertility, and negative effects on psychosocial quality of life [1-5]. Unfortunately, endometriosis is also a significant risk factor for development of ovarian cancer [6]. The presence of endometriosis increases the risk of ovarian endometrioid, low-grade serous, and clear-cell adenocarcinoma by up to 8.9-fold but not high-grade serous adenocarcinoma [7-12]. Thus, ovarian endometrioid, low-grade serous, and clear-cell adenocarcinomas are considered endometriosis-associated ovarian cancers. Ovarian cancer is considered a top-five cancer killer in U.S. women, claiming more than 14,000 lives in 2015 [13]. Therefore, 5 million U.S. women and girls with endometriosis are at risk for developing deadly ovarian cancer. Fortunately, ovarian endometrioid and clear-cell adenocarcinoma represent roughly $20 \%$ of all ovarian cancers and account for less than $10 \%$ of deaths [14-16]. Clinically, studies suggest that co-occurrence of endometriosis with ovarian cancer is associated with an improved prognosis [17-20]. Important factors in this improved prognosis include discovery at early age and early stage disease in women with endometriosis at time of ovarian cancer staging [21-24], but may 
also represent the unique biology from the endometriotic tumor microenvironment. This review will focus on the contributions of the endometriotic tumor microenvironment to ovarian cancer biology.

\section{Unique Molecular Features of Endometriosis-Associated Ovarian Cancer}

Each histotype of epithelial ovarian cancer is thought to arise from a distinct precursor lesion. For example, endometriosis is thought to give rise to both ovarian endometrioid and clear-cell adenocarcinomas [25]. Recently, sophisticated proteomic tracing studies suggest that ovarian endometrioid adenocarcinomas arise from secretory cells of endometriosis or the endometrium, while ovarian clear-cell adenocarcinomas arise from ciliated cells. Importantly, it is hypothesized that the unique cellular environment dictates the development of ciliated or secretory cells, which then gain mutations to become malignant [26]. Recently, next-generation sequencing studies showed mutations in cancer-driver genes (i.e., AT-rich interaction domain 1A (ARID1A), Phosphatidylinositol-4, 5-bisphosphate 3-kinase catalytic subunit alpha (PIK3CA), and Kirsten rat sarcoma viral oncogene homolog $(K R A S))$ in deep infiltrating endometriotic lesions, supporting the idea that the endometriotic microenvironment facilitates mutations [27]. Because deep infiltrating endometriotic lesions do not pose a risk of malignant transformation, the unique contributions of driver mutations in these particular endometriotic lesions are still relatively unknown [27]. Interestingly, these mutations in cancer-driver genes were only present in glandular epithelium and not underlying stroma [27]. These data support the idea that both epithelium and stromal populations of deep infiltrating endometriosis do not represent similar clonal populations. Further, this data may represent the idea that unique stromal populations are recruited to the area $[28,29]$. Detailed studies of unique genetic contributions of both epithelial and/or stromal compartments in malignant transformation are needed.

Studies examining endometriotic lesions and ovarian cancer from the same patient have shown concordant mutations in ARID1A, phosphatase and tensin homolog (PTEN), PIK3CA, and KRAS, suggesting that mutations in endometriosis cause a predisposition to ovarian cancer [30-33]. Mutations in KRAS and ARID1A have been discovered in endometriosis, including ovarian endometriosis and deep infiltrating endometriosis [27,34]. Loss of ARID1A is higher in atypical endometriosis and non-atypical endometriosis adjacent to ovarian cancer than non-atypical endometriotic distal lesions [30,32,35-39]. In general, both endometrioid and clear cell ovarian cancer with or without endometriosis have common high frequency mutations in ARID1A, PIK3CA, catenin betat 1 (CTNNB1), PTEN, and KRAS [33,40-45]. In terms of unique molecular features, $29 \%$ of low-grade ovarian endometrioid adenocarcinomas with concurrent endometriosis contained mutations in KRAS compared to 3\% of low-grade endometrioid adenocarcinomas lacking endometriosis [33]. Importantly, Ishikawa et al. showed high frequency of ARID1A mutations and one patient with both ARID1A and KRAS mutations in endometriosis-associated ovarian cancers [43]. The contributions of both ARID1A and KRAS warrant further study in terms of endometriosis, the endometriotic tumor microenvironment, and endometriosis-associated ovarian cancer.

In terms of low-grade serous tumors, an A to T substitution in BRAF has been identified in $36-68 \%$ of low-grade serous ovarian cancers and is associated with improved prognosis [46-48]. Additionally, increased expression of B-raf proto-oncogene, serine/threonine kinase (BRAF) was also noted in eutopic and ectopic endometrium of women with endometriosis when compared to control endometrium [49]. The contributions of BRAF to endometriosis and endometriosis-associated ovarian cancers, specifically, low-grade serous ovarian cancers are understudied.

In addition to mutational changes, epigenetic changes play a role in both endometriosis and endometriosis-associated ovarian cancers. Methylation changes in both endometriosis and endometriosis-associated ovarian cancer have recently been reviewed [50,51]. Along those lines, endometriosis tissues have decrease expression of ten-eleven translocation genes (TET1, TET2, and TET3), which convert 5-methylcytosine to 5-hydroxymethlcytosine and play a role in changes in levels of 5-hydroxymethylcytosine marks in endometriosis tissues and blood [52]. Unfortunately, the authors did not assess 5-hydroxymethlcytosine marks in specific genes. Further studies are needed 
in endometriosis-associated ovarian cancer to examine changes in these and other alternative DNA marks. MicroRNA (miRNA) molecules, which are also considered epigenetic changes, are dysregulated in endometriosis (reviewed in [53]). While dysregulated miRNAs in epithelial ovarian cancers have been recently reviewed [54,55], dysregulated miRNA molecules in endometriosis-associated ovarian cancers have not been individually reviewed. Given that miRNA molecules can be secreted from cells, we have included miRNA molecules under endometriotic tumor microenvironment (below).

A challenge to studies on the endometriotic tumor microenvironment is the rarity of clinical samples of ovarian cancer with concurrent endometriosis and the rigor of details provided for patient characterization. Given over 22,000 women will be diagnosed with ovarian cancer in 2016 [13], only 10\% will be endometrioid and roughly 10\% will be clear-cell [14-16]. Additionally, a majority of women with endometriosis-associated ovarian cancers do not have endometriosis at time of staging. Roughly $30 \%$ of ovarian endometrioid or clear-cell adenocarcinomas will have concurrent endometriosis, further narrowing the number of tumors to study with concurrent endometriosis [56-59]. Many studies do not describe the patient population in terms of absence or presence of endometriosis, leaving readers to believe that the women may not have endometriosis, which may not be accurate. Efforts for data harmonization for rare tumors may improve reproducibility. Using well-characterized samples, Banz et al. used transcriptome microarray analysis to evaluate normal ovary, endometriomas, and endometrioid ovarian cancer with and without endometriosis [60]. The results showed a small group of cytokines dysregulated in ovarian cancers with endometriosis, consistent with the inflammatory milieu of endometriosis [60]. Additionally, Zhang et al. showed a unique gene signature in ovarian endometrioid adenocarcinoma with concurrent endometriosis compared to ovarian endometrioid adenocarcinoma without concurrent endometriosis [61]. Highly dysregulated signaling pathways included nuclear factor kappa B (NFkB), transforming growth factor beta (TGF $\beta$ ), and KRAS signaling [61]. Most likely there are contributions from genetics and epigenetics that may be mediated from the endometriotic tumor microenvironment [62]. However, further studies are needed to examine how endometriosis affects ovarian cancer.

\section{The Unique Endometriotic Tumor Microenvironment}

While the pathogenesis of endometriosis is still largely poorly understood, the most accepted theory is the implantation theory following retrograde menstruation (reviewed in [63]). Most menstruating women have retrograde menstruation [64], but only $10 \%$ have endometriosis [1-3], suggesting that unique conditions occur in women with endometriosis. The endometriotic microenvironment contains multiple cell types-endometrial epithelial cells, stromal fibroblasts, endothelial cells, and immune cells-as well as inflammatory mediators, metabolic waste products such as iron from the breakdown of red blood cells, steroid hormones, and small RNA molecules. Thus, it is not surprising that the conditions found in endometriosis are also advantageous to the growth and development of ovarian cancer. However, very little is known about how these stressful conditions directly affect ovarian cancer. In this section, we will describe these important factors within the scope of endometriosis and how these important factors pertain to ovarian cancer. Figure 1 summarizes graphically key players in the endometriotic tumor microenvironment as it pertains to ovarian cancer.

\subsection{Hypoxia and Endothelial Cells}

Hypoxia is thought to be critical to the survival and invasion of endometriotic cells through multiple mechanisms including autophagy [65-68], TGF $\beta$ signaling [69], and signal transducer and activator of transcription 3 (STAT3) signaling [70-72]. In endometriosis, hypoxia stabilizes hypoxia inducible factor- $1 \alpha$ (HIF1A) which downregulates dual-specificity phosphatase-2 (DUSP2) directly and indirectly through miR-20a [73]. Ultimately, this downregulation leads to increased angiogenesis and proliferation through activation of extracellular signal-regulated kinase (ERK) signaling cascades $[73,74]$. As such, molecular immunohistochemistry shows a high correlation 
between precursor endometriosis lesions and matched clear-cell adenocarcinomas for expression of HIF1A and phosphorylated mechanistic target of rapamycin kinase (P-mTOR) [75]. Importantly, vascular endothelial growth factor (VEGF), leptin (LEP), cysteine rich angiongenic inducer 61 (CYR61), and osteopontin (SPP1) work together in response to hypoxia to establish a local vascular network within the endometriotic lesion [74]. In addition to neoangiogenesis mediated through HIF1A, as endometriotic lesions undergo hypoxia and inflammation from repeated menstrual cycles, the expression of tissue factor increases. Tissue factor is a critical protein for extrinsic coagulation cascade, leading to hypercoagulation. Clinically, women with clear-cell ovarian cancer have more frequent venous thromboembolism [76]. Hypoxia may also lead to cellular proliferation through estrogen receptor, leptin, and prostaglandin modulation [77]. These studies suggest that the hypoxic microenvironment of endometriosis plays a role in not only the potentiation of endometriosis by promoting cell proliferation and nutrient availability through vascularization but may also play roles in outcomes for women with clear-cell ovarian cancer. The increased expression of HIF1A in endometriosis may represent a novel therapeutic target for endometriosis or ovarian cancer [78].

\subsection{Fibroblasts and Extracellular Matrix Components}

Endometriosis is pathologically complex, containing endometrial epithelial and stromal fibroblasts outside the uterine cavity, alongside invading hemosiderin-laden macrophages [79]. The endometriotic extracellular matrix (ECM) plays a significant role in paracrine/autocrine signaling between epithelial and stromal cells [80-83]. Studies have shown unique functional properties of primary cultures of human endometrial stromal fibroblasts from women with endometriosis compared to cultures from women without endometriosis. Specifically, fibroblast cultures from women with endometriosis have a deficiency in decidualization, the differentiation process by which the uterus prepares for pregnancy [84]. Additionally, these fibroblasts from women with endometriosis have increased ERK signaling, high proliferative potential from progesterone resistance, and acquire an inflammatory phenotype [85-89]. While the importance of stromal-epithelial crosstalk is noted in embryo implantation in the uterus [80], the role of similar crosstalk in endometriosis or epithelial ovarian cancers is still understudied but may represent a key component of the endometriotic tumor microenvironment.

To examine the tumor microenvironment in ovarian cancer, Zhang et al. used computer-aided image analysis and showed that the number of cancer-associated fibroblasts, as indicated by cells positive for smooth muscle antigen, was higher in epithelial ovarian cancers compared to benign adnexal masses. Unfortunately, the specific histology of ovarian cancers and the pathology of the benign adnexal masses were not described in these studies. Large numbers of similarly staining cancer-associated fibroblasts were also found in omental metastatic lesions [90]. Co-culture of cancer-associated fibroblast with ovarian cancer cell lines (SKOV3, CAOV3) led to increased invasion and migration when compared to ovarian cancer cell lines grown in co-culture with normal fibroblasts [90]. One of the main questions regarding cancer-associated fibroblasts is how and why they are becoming activated to benefit tumor cells. Mitra et al. proposed that ovarian cancer cells reprogram fibroblasts into cancer-associated fibroblasts through miRNA expression changes [91]. Specifically, cancer-associated fibroblasts have a significant downregulation of miR-31 and miR-214 and upregulation of miR-155. C-C motif ligand 5 (CCL5), a chemokine known to be highly upregulated in ovarian cancers, is a direct target of miR-214. Similarly, endometriomas have high expression of chemokines and dysregulated miRNA expression [92]. Advancements in the understanding of the role of non-epithelial ovarian cancer cells in ovarian cancer may lead to better treatments which block tumor promotion brought on by tumor adjacent cells.

\subsection{Immune Cells and Inflammatory Mediators}

Dysregulated inflammation plays a key role in endometriosis-associated pathology [93]. For example, Capobianco and Rovere-Querini provide an in-depth review of the role of macrophages 
in endometriosis, showing a relationship between components of the endometriotic microenvironment such as high iron, hypoxia, and angiogenesis with macrophage recruitment and activation [94]. Additionally, a syngeneic mouse model of endometriosis showed that endometriotic lesions failed to grow without macrophages, and if macrophages were removed after implantation, angiogenesis was halted, blocking the progression of the endometriotic lesion [95]. Further, Canet et al. suggest that retainment of a specific macrophage population in endometriomas, the cell division cycle 42 (CDC42)-positive population, protects endometriomas from malignant transformation [96]. Similarly, platelet factor 4 (PF4) also known as chemokine (C-X-C Motif) ligand 4 (CXCL4) is highly expressed on macrophages in endometriomas, but not on tumor-associated macrophages of clear cell ovarian cancers [97]. Thus, specific details of the macrophage population in endometriosis and ovarian cancer are important and require further study.

Transcriptomic work on endometriomas showed that the inflammatory cytokine transforming growth factor beta 1 (TGF $\beta 1$ ), regulates other inflammatory mediators relevant to endometriosis, including tumor necrosis factor alpha (TNF $\alpha$ ) and interleukin-6 (IL6) [92]. These inflammatory mediators are highly elevated in peritoneal fluid from women with endometriosis [98-101]. The acute and chronic inflammation of endometriosis is a response to the invading tissue, leading to the release of regulated on activation normal $\mathrm{T}$ cell expressed and secreted (RANTES), monocyte chemotactic protein-1 (MCP1), and interleukin-8 (IL8), which act as chemoattractants recruiting more macrophages to the area [102]. In terms of the endometriotic tumor microenvironment, the promotion of tumor invasion via macrophages may be dependent on TNF $\alpha$ [103], which is elevated in women with endometriosis $[98,99]$. Along the same lines, work using an estrogen receptor beta (ER $\beta$ )-overexpressing syngeneic mouse model of endometriosis suggests that non-genomic effects of ER $\beta$ play a role in the TNF $\alpha$-mediated dysregulation of endometriosis progression [104]. Encouragingly, treatment of a syngeneic mouse model of endometriosis with a long-acting TNF $\alpha$-blocking agent decreased endometriotic implant size [105]. However, treatment of women with rectovaginal nodules with infliximab, a TNF $\alpha$ monoclonal antibody, had no improved clinical effect over placebo [106]. Understanding the immune response to misplaced endometrial tissue will be a large factor in understanding the onset and progression of endometriosis and lead to a better understanding of how endometriosis creates a unique and potentially tumor-promoting microenvironment.

\subsection{Altered Metabolism}

Endometriotic cysts contain blood. When blood is metabolized, heme and iron are released into the microenvironment [107]. Because of this, endometriotic cysts contain higher iron levels than other benign ovarian cysts [108]. Consequently, an iron-rich microenvironment can lead to increased proliferation, DNA synthesis, and adhesion, and promote chronic inflammation, allowing for the spread of endometriosis [107]. High iron also leads to excessive oxidative stress, which creates a microenvironment conducive to the induction of mutations and has been linked to cancer development in the liver and lung $[107,109]$. Shigetomi et al. outlines how endometriotic cells under oxidative stress from excess iron are able to bypass cell cycle checkpoints after DNA damage by overexpressing hepatocyte nuclear factor-1 beta (HNF1B), which activates forkhead box transcription factors and alters miRNA expression promoting cell survival [110]. Due to the excess iron exposure, endometriotic cysts have higher expression of lactose dehydogenase, lipid peroxidase, and 8-hydroxy-2'-deoxyguanosine. High expression of these markers of oxidative stress link endometriosis, high iron, and higher frequencies of gene mutations [108]. These data corroborate the hypothesis that endometriosis produces a high iron microenvironment that may lead to increased DNA damage through oxidative stress, but also promotes cell survival, leading to a highly mutated subpopulation of cells that continue to grow [111].

Alongside high iron levels, endometriotic peritoneal fluid has elevated lactate. Further, endometriotic lesions express high levels of glycolysis genes compared to eutopic endometrium [112]. Increased expression of $\mathrm{HNF} 1 \alpha$ in the endometriotic peritoneum leads to the conversion of glucose to 
lactate in a process known as the "Warburg Effect," known for its promotion of cell survival in stressful microenvironments [113]. Lipidomics has also been pursued for understanding the metabolomic profile of the endometriotic microenvironment. Lipid profiling studies on endometrial aspirates have shown a reduction of saturated diacylglycerols and triacylglycerols in endometriosis patients compared to healthy controls [114]. In fact, this study generated a panel of 123 metabolites which were differentially expressed in endometriosis women and correctly identified $86 \%$ of samples to either the endometriosis or control group [114]. A similar study on endometrial biopsies used five lipid metabolites as biomarkers and were able to predict endometriosis with $75 \%$ specificity and $90.5 \%$ sensitivity [115]. A true model of the endometriotic tumor microenvironment should include increased iron levels, higher levels of glycolysis-associated proteins, and endometriosis-associated lipidomic profiles.

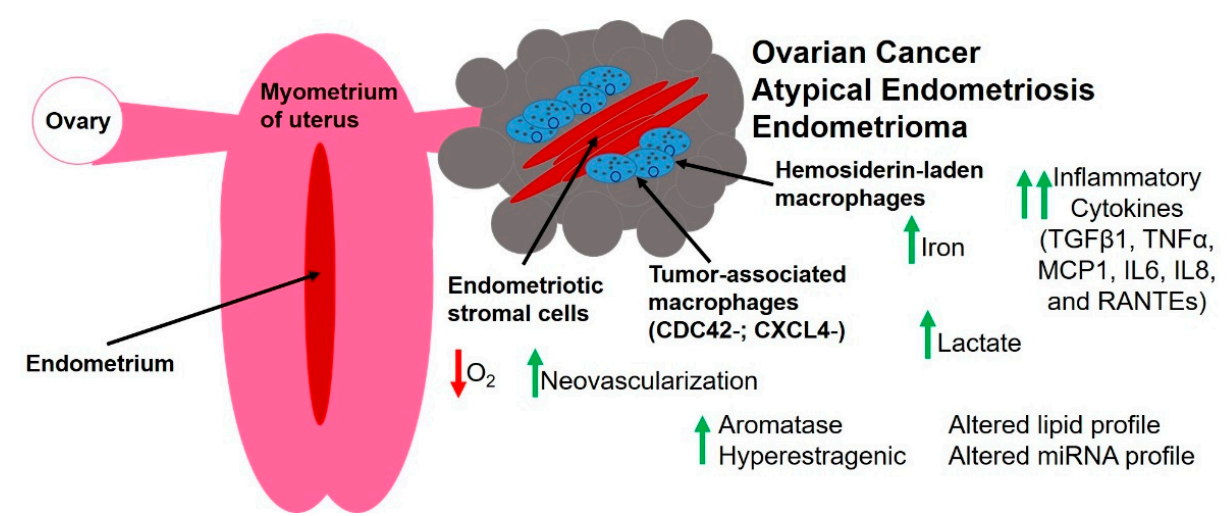

Figure 1. Composition of the endometriotic tumor microenvironment. Endometriosis represents a pathologically benign disease. Endometriosis may be classified into endometriomas, superficial peritoneal disease, or deep infiltrating endometriosis (invasion $>5 \mathrm{~mm}$ ). Although deep infiltrating endometriosis is invading, typically into the muscularis layer of the bowel, it is clinically not associated with ovarian cancer. Endometriomas are epithelial lined cysts of the ovary, which can be filled with a brown cyst fluid, and thus the name "chocolate cysts." Endometriomas can be associated with ovarian cancer, with atypical endometriomas having a higher risk of malignant transformation. Atypical endometriomas are characterized by epithelial cells with enlarged hyperchromatic and pleomorphic nuclei, with cellular crowding and high nuclear-to-cytoplasmic ratio. The altered endometriotic tumor microenvironment may lead to malignant transformation or propagation of proliferative potential [107]. RANTES: regulated on activation normal T cell expressed and secreted; MCP1: monocyte chemotactic protein-1; IL: interleukin; TGF $\beta 1$ : transforming growth factor beta 1; TNF $\alpha$ : tumor necrosis factor alpha; CDC42: cell division cycle 42; CXCL4: chemokine (C-X-C motif) ligand 4 .

\subsection{Steroid Hormones}

Endometriosis is an estrogen-responsive disorder with lesion-level hyperestrogenism. Specifically, endometriotic tissue differs from eutopic endometrial tissue by the high expression of aromatase (CYP19A1) and 17 $\beta$-hydroxysteroid-dehydrogenase (17 $\beta$-HSD) type 1 and the absence of $17 \beta-H S D$ type $2[107,116]$. Aromatase converts androstenedione or testosterone to estrone and estradiol at the level of the endometriotic microenvironment. High levels of estradiol have been linked to IL8 and RANTES production, which facilitate proliferation, inflammation, and feedback to increased expression of aromatase $[107,117]$. Aromatase activity is also stimulated through prostaglandin $\mathrm{E}_{2}$, an inflammatory product of cyclooxygenase 1 and 2 (COX1/2), found in endometriotic lesions in high levels [118]. Inhibitors of prostaglandin E2 receptor show promising effects in a xenograft model of endometriosis [119]. At the endometriotic lesion level, there is significant feed forward production and maintenance of estrogen, associated with pro-tumorigenic qualities. Medical management 
of endometriosis with oral contraceptives lowers overall steroid hormone levels. This may explain why the protection from combined oral contraceptive therapy on ovarian cancer risk is more robust for women with endometriosis (odds ratio $0.21(0.08-0.58), p=0.003)$ compared to non-endometriosis population (odds ratio $0.47(0.37-0.61, p<0.001)$ ) [120]. Thus, the role of steroid hormones on endometriosis-associated ovarian cancers needs further study.

\subsection{Small RNA Molecules}

Small RNA molecules are non-coding RNA molecules that can play an important role in the post-transcriptional regulation of gene expression. Multiple groups of small RNAs have been identified, such as microRNAs (miRNAs), small nucleolar RNA (snoRNAs), small interfering RNAs (siRNAs), and Piwi-interacting RNA (piRNAs) [121]. The most studied type of small RNA molecules in endometriosis-associated ovarian cancers are miRNAs. In general, miRNAs regulate gene expression by mRNA cleavage and translational repression [122,123]. Studies have shown that miRNAs are frequently dysregulated in endometriosis and endometriosis-associated ovarian cancers (reviewed in [53-55]). Compilation of dysregulated miRNAs in ovarian endometrioid and clear-cell adenocarcinomas, as well as endometriosis (Supplemental Table S1) shows dysregulated miRNA molecules for each tissue type [53,55,124-133]. Figure 2 shows the number of miRNAs dysregulated in ovarian clear-cell and endometrioid adenocarcinomas, and endometriosis tissues. Supplemental Table S1 details the specific miRNA molecules in the each unique and overlapping group. MiR-126 was found downregulated in all three groups. While the function of miR-126 is still unknown, miR-126 was significantly downregulated in endometriosis compared with eutopic endometrium [134]. Additionally, downregulation of miR-126 induced non-ovarian cancer cell proliferation, migration, and invasion, mediated through numerous validated targets, such as PI3K, KRAS, and VEGF. Reduced levels of miR-126 were a significant predictor of poor survival of cancer patients, although women with ovarian cancer were not included in the study [135]. Thus, miR-126 may play a role in endometriosis and ovarian cancer, even though these functional studies did not have ovarian cancer samples with concurrent endometriosis.

A

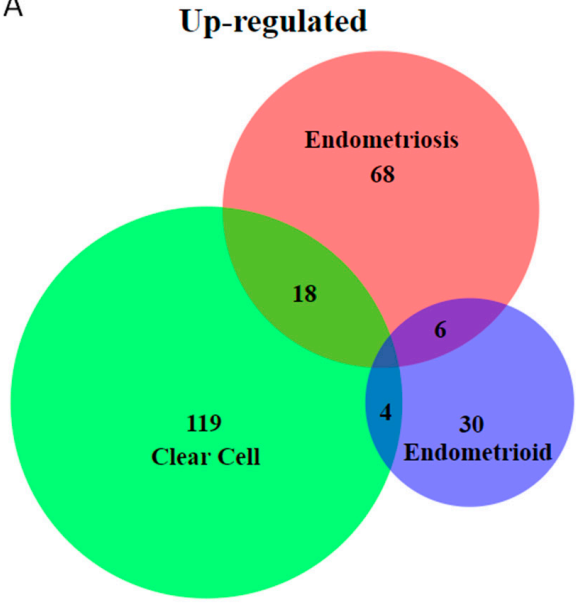

B

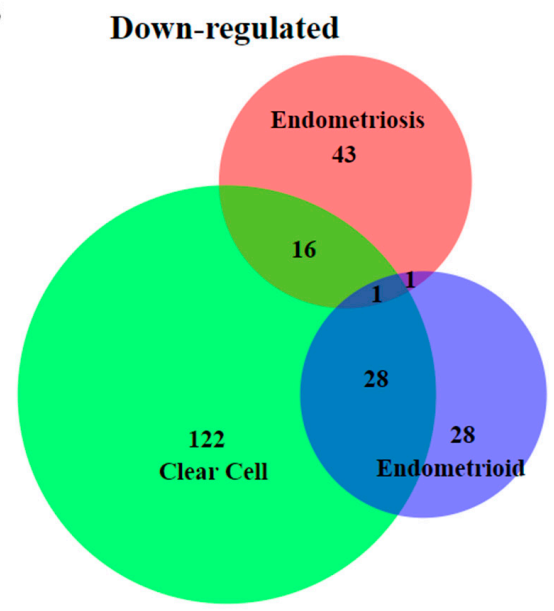

Figure 2. Venn diagram of overlap of number of miRNAs differentially expressed in endometriosis and ovarian clear-cell and endometrioid adenocarcinoma. The miRNAs differentially expressed are depicted in three overlapping circles. The numbers indicate the miRNA counts that are unique or in common between the groups. (A) Upregulated miRNAs; (B) downregulated miRNAs. Supplemental Table S1 details the miRNAs in each group above.

MiR-30a, miR-30c, miR-31, miR-532-5p, and miR-885-5p were upregulated in clear cell ovarian cancer by multiple studies [124-127,131,132]. MiR-30 was found to be 5-fold overexpressed in ovarian clear-cell adenocarcinoma [132]. Sestito et al. showed that overexpression of miR-30a 
delayed tumor formation in xenograft tumors, and overexpression of miR-30a sensitized ovarian cancer cells to chemotherapy [136]. Downregulation of miR-532 was associated with poor survival in women with ovarian cancer, and overexpression of miR-532 suppressed the proliferative and invasive capacity of the ovarian cancer cell lines, ES2 and SKOV-3, and inhibited tumor growth in vivo [137]. Endometrioid ovarian cancer had the shortest list of dysregulated miRNAs (Figure 2 and Supplemental Table S1). MiR-200 family miRNAs (miR-200a, -200b, -200c, -141, and -429) were upregulated in ovarian cancer and may play crucial roles in ovarian cancer metastasis, diagnosis, and treatment $[126,129,130,138]$.

\section{Model Systems for Studying Rare Ovarian Cancers}

Multiple model systems have been employed to study endometriosis and endometriosisassociated ovarian cancers (reviewed in $[139,140]$ ). This review will highlight the tumor microenvironment of the genetically engineered mouse models of endometriosis-associated ovarian cancers. We have chosen to focus on spontaneous models instead of transplant models (reviewed in [140]). Because there has yet to be a comprehensive mouse model that replicates ovarian cancer with endometriosis, this review will also focus on the role of immortalized cell lines, xenograft models, co-culture systems, and three-dimensional (3D) models.

\subsection{Genetically Engineered Mouse Models}

\subsubsection{Candidate Genes in Genetically Engineered Mouse Models}

High-grade serous ovarian cancer is a genomically complex disease [141] and although neither endometrioid nor clear-cell ovarian cancer have been as extensively profiled, they are likely complex as well. For the study of genetically engineered mouse models, fortunately, both endometrioid and clear cell ovarian cancer have high frequency mutations in only a handful of genes: ARID1A, PIK3CA, CTNNB1, PTEN, and KRAS [33,40-42,44,45]. Use of traditional Cre recombinase technology with candidate-gene floxed alleles has had mixed results in terms of single gene knockout developing endometriosis-associated ovarian cancers. Table 1 lists the promoters driving Cre recombinase, and Table 2 details the brief rationale behind the use of specific genes in these mouse models. Table 3 lists these genes with combinations of tissue-specific promoters driving $\mathrm{Cre}$ recombinase. Despite the promising allele targets and the tissue-specific promoters driving Cre recombinase, there are no genetic mouse models of endometriosis and concurrent ovarian cancer. Investigators have created genetically engineered mouse models, which developed ovarian low-grade serous, clear-cell, or endometrioid adenocarcinoma (Table 3). However, none of these models have concurrent endometriosis. This suggests that different genetic combinations are required to model concurrent endometriosis and ovarian cancer. The discussion below highlights the role of the microenvironment of each model, and how this microenvironment may be playing a role in ovarian cancer development. Even though the presented models do not completely represent the endometriotic tumor microenvironment, they are still useful for understanding development of endometrioid or clear-cell ovarian cancer.

Table 1. Cre recombinase promoters and site of effects.

\begin{tabular}{cccc}
\hline Cre & Gene Promoter & Location of Expression & Ref. \\
\hline Adenovirus (Ad) & Cytomegalovirus & Injection site & {$[142]$} \\
\hline Amhr2 & $\begin{array}{c}\text { Anti-Mullërian hormone } \\
\text { receptor type 2 }\end{array}$ & $\begin{array}{c}\text { Oviduct: stroma } \\
\text { Oterus: stroma and smooth muscle cells }\end{array}$ & {$[143,144]$} \\
\hline Cyp19 & Cytochrome P450 family 19 & Granulosa cells of antral follicles and luteal cells & {$[145]$} \\
\hline Ovgp1 & Oviductal glycoprotein 1 & Non-ciliated oviductal epithelial cells & {$[146]$} \\
\hline Pax8 & Paired box gene 8 & Fallopian tube, cervix, uterus, and endometrium & {$[147]$} \\
\hline Pgr & Progesterone receptor & $\begin{array}{c}\text { Oviduct: epithelium } \\
\text { Uterus: epithelium, stroma, myometrium } \\
\text { Ovary: time-limited granulosa cells }\end{array}$ & {$[148]$} \\
\hline
\end{tabular}


Table 2. Genes important in mouse models of endometriosis-associated ovarian cancer.

\begin{tabular}{|c|c|c|c|}
\hline Mouse Allele & Gene Name and Mouse Ref & Effect of Cre Recombination & Endometriosis-Associated Ovarian Cancer Implications and Ref. \\
\hline Arid $1 a^{f / f}$ & AT-rich interactive domain $1 \mathrm{~A}$ & ARID1A loss & $\begin{array}{l}46-95 \% \text { of clear-cell and } 30 \% \text { of endometrioid tumors have loss of } \\
\text { ARID1A [30,43-45] }\end{array}$ \\
\hline$A p c^{f / f}$ & Adenomatous polyposis coli & Overexpression of $\beta$-catenin & $\begin{array}{l}\text { Mutations in APC lead to activation of } \beta \text {-catenin which is frequently } \\
\text { activated in endometrioisis-associated ovarian cancers [149] }\end{array}$ \\
\hline Ctnnb1/f & Catenin beta-1 & Overexpression of $\beta$-catenin & $\begin{array}{l}\text { 16-54\% of endometriod ovarian cancers have mutations in } \beta \text {-catenin, } \\
\text { leading to nuclear localization, and activation of wingless integration } \\
\text { site (WNT) signaling [150-153] }\end{array}$ \\
\hline Kras $^{l s l-G 12 D}$ & Kirsten rat sarcoma & Expression of oncogenic Kras & $\begin{array}{l}29 \% \text { of low-grade endometrioid ovarian tumors with concurrent } \\
\text { endometriosis [33] }\end{array}$ \\
\hline$M U C 1^{+/-}$ & Mucin 1 & Expression human MUC1 in mouse & $\begin{array}{l}\text { Expressed in endometrium and endometriosis; potential biomarker for } \\
\text { endometriosis or ovarian cancer [154] }\end{array}$ \\
\hline Pik3ca ${ }^{H 1047 R}$ & $\begin{array}{l}\text { Phosphatidylinositol-4,5-bisphosphate } \\
\text { 3-kinase catalytic subunit alpha }\end{array}$ & Mutation in Pik3ca kinase domain & $\begin{array}{l}20 \% \text { of clear-cell and } 20 \% \text { of endometrioid ovarian cancers with } \\
\text { mutations [155] }\end{array}$ \\
\hline Ptent/f & Phosphatase and tensin homolog & PTEN loss and activation of AKT & $20 \%$ of clear-cell and $20 \%$ of endometrioid cancers [156] \\
\hline
\end{tabular}

Table 3. Mouse models with implications in endometriosis and endometriosis-associated ovarian cancers.

\begin{tabular}{|c|c|c|c|c|}
\hline Genotype & Phenotype & Penetrance & Details & Ref. \\
\hline $\begin{array}{l}\text { Arid1 } a^{\mathrm{flf}} ; \text { Ad }{ }^{\mathrm{Cre}} \\
\text { (Ovarian bursa) }\end{array}$ & No cancer & $\begin{array}{l}0 / 29 \text { with adnexal masses } \\
0 / 42 \text { with adnexal masses }\end{array}$ & No endometriosis & {$[157,158]$} \\
\hline Arid1afff;Amhr2 $2^{\mathrm{Cre}}$ & No cancer & $0 / 20$ with adnexal masses & No endometriosis & [159] \\
\hline Arid1 aff $; \mathrm{Pgr}$ Cre & No cancer & $0 / 20$ with adnexal masses & No endometriosis & [160] \\
\hline $\begin{array}{l}\text { Pten }^{f / f} ; A d^{C r e} \\
\text { (Ovarian bursa) }\end{array}$ & No cancer & $\begin{array}{l}0 / 5 \text { with adnexal masses } \\
0 / 63 \text { with adnexal masses }\end{array}$ & No endometriosis & {$[158,161]$} \\
\hline $\begin{array}{l}P_{t e n} f / f ; A d d^{C r e} \\
\text { (Infundibulum to ovarian bursa) }\end{array}$ & Low penetrance endometrioid ovarian cancer at 26 weeks & $\begin{array}{l}8 / 13 \text { with ovarian endometriosis like lesions } \\
1 / 13 \text { with ovarian cancer by } 26 \text { weeks }\end{array}$ & $\begin{array}{l}\text { Endometriosis-like lesions of ovary (lacked } \\
\text { stromal component) }\end{array}$ & [162] \\
\hline Ptenff; ;Cyp19Cre & No cancer & $0 / 4$ with adnexal masses & No endometriosis & [163] \\
\hline Pten ${ }^{f / f} ; A m h r 2^{C r e}$ & Granulosa cell tumor & $5 / 70$ with ovarian cancers by 7 months & No endometriosis & [164] \\
\hline Pten ${ }^{f / f} ; A p d^{f / f} ; O v g p 1^{\mathrm{Cre}}$ & Endometrioid ovarian carcinoma & $10 / 15$ with ovarian cancers & Metastatic lesions & [146] \\
\hline Ptenfff; Pax $8^{\mathrm{Cre}}$ & Endometrioid oviductal adenocarcinoma & $3 / 4$ with oviductal cancers by 7 months & Oviductal tumors metastasized to ovary & [147] \\
\hline
\end{tabular}


Table 3. Cont

\begin{tabular}{|c|c|c|c|c|}
\hline Genotype & Phenotype & Penetrance & Details & Ref. \\
\hline 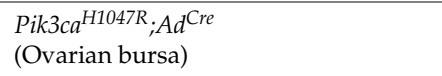 & No cancer & $0 / 6$ with adnexal masses & $\begin{array}{l}4 / 5 \text { ovarian surface epithelium hyperplasia } \\
\text { (microscopic) }\end{array}$ & [157] \\
\hline $\begin{array}{l}\mathrm{Kras}^{G 12 D} ; A d^{C r e} \\
\text { (Infundibulum to ovarian bursa) }\end{array}$ & $15 / 15$ endometriosis-like lesions of ovary & $15 / 15$ with endometriosis-like lesions of ovary & $\begin{array}{l}\text { Endometriosis-like lesions of ovary (lacked } \\
\text { stromal component) }\end{array}$ & [162] \\
\hline $\begin{array}{l}\mathrm{KraS}^{G 12 D} ; \mathrm{Ad}^{\mathrm{Cre}} \\
\text { (Uterotubal injection to ovarian bursa) }\end{array}$ & $7 / 15$ with peritoneal endometriosis & $7 / 15$ with peritoneal endometriosis & Peritoneal endometriosis & [162] \\
\hline $\begin{array}{l}\text { Kras }{ }^{G 12 D} ; A d^{C r e} \\
\text { (IP injection) }\end{array}$ & No cancer & $0 / 13$ with adnexal masses & No endometriosis & [162] \\
\hline $\mathrm{Kras}^{\mathrm{G} 12 \mathrm{D}} ; \mathrm{Amhr} 2^{\mathrm{Cre}}$ & No cancer & $0 / 4$ with adnexal masses & $\begin{array}{l}\text { No endometriosis } \\
\text { Abnormal follicles }\end{array}$ & {$[145,163]$} \\
\hline $\mathrm{Kras}^{\mathrm{G} 12 \mathrm{D}} ; \mathrm{Cyp} 19^{\mathrm{Cre}}$ & No cancer & $0 / 4$ with adnexal masses & $\begin{array}{l}\text { No endometriosis } \\
\text { Abnormal follicles }\end{array}$ & {$[145,163]$} \\
\hline $\mathrm{Kras}^{\mathrm{G} 12 \mathrm{D}} ; \mathrm{Pgr}{ }^{\mathrm{Cre}}$ & No cancer & $0 / 3$ with adnexal masses & No endometriosis & [163] \\
\hline $\mathrm{Ctnnb}^{\mathrm{fl+}} ; \mathrm{Amhr} 2^{\mathrm{Cre}}$ & Endometrioid ovarian carcinoma & $5 / 6$ with ovarian cancer by 6 months & No endometriosis & [165] \\
\hline $\begin{array}{l}\text { Arid1 } 1 a^{f / f} ; P i k 3 c a^{H 1047 R} ; A d^{C r e} \\
\text { (Ovarian bursa) }\end{array}$ & Poorly differentiated clear-cell ovarian carcinoma & $23 / 30$ with ovarian cancer by 7 weeks & $\begin{array}{l}77 \% \text { penetrance } \\
\text { No endometriosis } \\
\text { Aggressive metastatic tumors }\end{array}$ & [157] \\
\hline $\begin{array}{l}\text { Arid1 1 } a^{f f f} ; \text { Pten } n^{f f} ; \text { Ad } d^{\text {Cre }} \\
\text { (Ovarian bursa) }\end{array}$ & $\begin{array}{l}\text { 5/13 endometrioid ovarian carcinoma } \\
8 / 13 \text { undifferentiated adenocarcinoma }\end{array}$ & $13 / 22$ with ovarian cancer by 9 months & $\begin{array}{l}59 \% \text { penetrance } \\
\text { No endometriosis } \\
\text { Aggressive undifferentiated tumors }\end{array}$ & [158] \\
\hline Apclff; $; \mathrm{Pgr}^{\mathrm{Cre}}$ & Endometrioid ovarian carcinoma & $12 / 43$ with ovarian cancer & $\begin{array}{l}\text { No endometriosis } \\
16 \% \text { endometrioid ovarian cysts }\end{array}$ & [166] \\
\hline $\begin{array}{l}\text { Pten } \text { fff }_{\text {; }} \text { Apctff; } ; d^{C r e} \\
\text { (Ovarian bursa) }\end{array}$ & Endometrioid ovarian carcinoma & $29 / 29$ with ovarian cancer & $\begin{array}{l}100 \% \text { penetrance } \\
\text { No endometriosis } \\
\text { Aggressive metastatic tumors }\end{array}$ & [161] \\
\hline 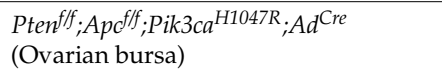 & Endometrioid ovarian carcinoma & $11 / 11$ with ovarian cancer & $\begin{array}{l}\text { No endometriosis } \\
\text { Aggressive metastatic tumors }\end{array}$ & [167] \\
\hline $\begin{array}{l}\mathrm{Krag}^{\mathrm{G} 12 D} ; \mathrm{Pten}^{\mathrm{fff}} ; \mathrm{Ad}^{\mathrm{Cre}} \\
\text { (Infundibulum to ovarian bursa) }\end{array}$ & Endometrioid ovarian carcinoma & 9/9 with ovarian cancer by 12 weeks & $\begin{array}{l}100 \% \text { penetrance } \\
\text { Aggressive metastatic disease } \\
\text { No endometriosis }\end{array}$ & [162] \\
\hline $\begin{array}{l}\text { MUC1 }{ }^{+-} ; \mathrm{Kras}^{\mathrm{G} 12 \mathrm{D}} ; \mathrm{Ad} \mathrm{Cre}^{\mathrm{re}} \\
\text { (Ovarian bursa) }\end{array}$ & Endometriosis-like lesions of ovary & No ovarian cancer & endometriosis-like lesions of ovary & [168] \\
\hline $\mathrm{Ctnnbf}^{f /+} ; \mathrm{Pten}^{f f} ; \mathrm{Amhr} 2^{\mathrm{Cre}}$ & Endometrioid ovarian carcinoma & $5 / 5$ with ovarian cancer by 6 weeks & No endometriosis & [165] \\
\hline $\mathrm{Kras}^{\mathrm{G} 12 D} ; \mathrm{Pten}^{\text {fff }} ; \mathrm{Amhr} 2^{\mathrm{Cre}}$ & Low grade ovarian serous papillary adenocarcinomas & $100 \%$ with ovarian tumors by 10 weeks & No endometriosis & {$[143,163]$} \\
\hline $\mathrm{Kras}^{\mathrm{G}}{ }^{2 D} ; \mathrm{Pten}{ }^{\mathrm{flf}} ; \mathrm{Pgr} \mathrm{Cre}$ & No cancer & $0 / 3$ with adnexal masses & No endometriosis & [163] \\
\hline $\mathrm{Kras}^{\mathrm{G} 12 \mathrm{D}} ; \mathrm{Pten}^{\mathrm{fff}} ; \mathrm{Cyp} 19^{\mathrm{Cre}}$ & No cancer & $0 / 3$ with adnexal masses & No endometriosis & [163] \\
\hline
\end{tabular}




\subsubsection{Endometriosis}

The only genetically engineered mouse model to spontaneously develop endometriosis with a single gene change is a highly innovative mouse model developed by Dinulescu et al. [162]. Using an oncogenic KRAS knock-in allele mouse $\left(\right.$ Kras $\left.^{G 12 D}\right)$, peritoneal endometriosis developed after injection of adenovirus-driven $\mathrm{Cre}\left(\mathrm{Ad}^{\mathrm{Cre}}\right)$ through the uterotubal junction to infect the ovarian bursa. This true peritoneal endometriosis model contained glandular epithelium and stromal components validated by molecular immunohistochemistry to cytokeratin 7,8 , and 20, estrogen receptor, progesterone receptor, smooth muscle actin, and CD10 [162]. Conversely, when $\mathrm{Ad}^{\mathrm{Cre}}$ was injected through the infundibulum to the ovarian bursa, the model develops ovarian endometriosis-like lesions without the stromal component [162]. A transplantation experiment hints that the peritoneal endometriosis is uterine or tubal in origin while the ovarian endometriosis-like lesions are ovarian surface epithelium derived [162]. While long-term follow up showed no development of ovarian cancer, future studies into the molecular lineage using secretory or ciliary markers may allow better definition of cell of origin [26,62]. A similar mouse model adds human mucin 1 (MUC1) to oncogenic Kras ${ }^{G 12 D}$ with $\mathrm{Ad}^{\mathrm{Cre}}$ intrabursal injection [168]. This mouse model similarly exhibits endometriosis-like lesions of the ovary. Importantly, these mice developed an immune response to MUC1 with high numbers of CD4+ Foxp3+ regulatory T cells in para-aortic lymph nodes compared to uninjected mice without lesions [168]. Models which recapitulate the immune response are needed to study the endometriotic tumor microenvironment.

Because mice do not normally menstruate, modeling retrograde menstruation requires significant manipulation. In homologous mouse models of endometriosis, endometrium from an estrogenprimed donor mouse is injected into a syngeneic estrogen-treated recipient mouse. However, homologous mouse models such as these grow poorly without exogenous estrogen [162]. A variation is the menstrual mouse model. In this model, the donor mouse undergoes significant hormonal manipulation followed by a stimulation of the uterus leading to decidualization. Hormone withdrawal leads to degeneration of the endometrium with leukocyte invasion, similar to menstruation in women [169-171]. Donor sloughed endometrium is then placed into recipient syngeneic mouse. Using this approach, Cheng et al. placed oncogenic Kras ${ }^{G 12 V}$ endometrial tissue into the subcuticular ventral abdomen of syngeneic mice without exogenous hormonal stimulation or matrix [172]. These lesions contained glandular epithelium, stroma, immune cells, extracellular matrix, and blood vessels with both estrogen receptor alpha and beta expression [172]. Similarly, Greaves et al. used a similar approach with endometrial tissue from a menstrual model of wild type mice. Using hormonally stimulated receptor mice, injection of tissue intraperitoneal with this non-genetically modified endometrial tissue leads to peritoneal endometriosis [173]. Again, these tissues were histologically and molecularly similar to human endometriosis [173]. Hormonal levels (i.e., endogenous versus exogenous high levels), tissue placement (i.e., subcuticular versus intraperitoneal), and genetic changes important to endometriosis-associated ovarian cancers (i.e., oncogenic KRAS, loss of function ARID1A) must be considered when using these menstrual endometriosis models. Additionally, genetically engineered mouse models that are unable to undergo decidualization such as $\mathrm{Pgr}^{\mathrm{Cre}}$;Arid1 $\mathrm{fflf}^{\mathrm{ff}}$ mice [160] do not allow such studies.

\subsubsection{Clear Cell Ovarian Cancer}

Poorly differentiated clear-cell ovarian carcinoma develops at 7.5 weeks post-injection in $A d^{\mathrm{Cre}} ;$ Arid $1 a^{\mathrm{fff}} ; \mathrm{Pik} 3 \mathrm{ca}{ }^{* H 1047 \mathrm{R}}$ female mice with $77 \%$ penetrance and with $57 \%$ of injected mice having peritoneal metastasis [157]. Similar deletion of ARID1A alone or with knock-in of Pik3ca mutations showed ovarian surface epithelium hyperplasia but no endometriosis $[157,158]$. Although clear cell features are present two weeks post-injection, endometriotic-like lesions are not described [157]. Microarray analysis, comparing primary ovarian tumors to contralateral un-injected ovary, found almost 600 genes dysregulated with significant enrichment in immune system function [157]. Consistent with an endometriotic tumor microenvironment, IL6 signaling was found to be increased 
in the primary tumors, peritoneal metastases, body fluids, and ascites [157]. IL6 signaling and tumor cell growth was blocked with IL6 neutralizing antibodies. While IL6 expression was also implicated in normal ovarian surface epithelium hyperplasia with ARID1A deletion or Pik3ca mutation alone, the combination further enhanced IL6 production [157]. Cross-species, global gene expression profiling showed similar dysregulated genes in this mouse model compared to ovarian clear-cell adenocarcinoma from women [174]. Together these data suggest that the deletion of ARID1A and mutation in $P i k 3 c a^{* H 1057 R}$ results in increased IL6 expression leading to the ovarian surface epithelial hyperplasia and eventually clear cell ovarian cancer. These tumor cells perpetuate IL6 production, creating a positive feedback loop of increased IL6 and increased cell (normal and cancerous) proliferation $[157,174]$. This interaction highlights how the tumor and its microenvironment can interact with one another to generate a more tumor-promoting environment.

\subsubsection{Endometrioid}

ARID1A, PIK3CA, CTNNB1, PTEN, and KRAS [33,40-42,44,45] are commonly mutated in both endometrioid and clear cell ovarian cancers from women. However, manipulation of these genes in mice typically results in endometrioid but not clear cell ovarian cancer. On injection of adenovirus-driven Cre $\left(A d^{C r e}\right)$ into the ovarian bursa through the infundibulum of Pten $^{f / f} ; \mathrm{Kras}^{G 12 D}$ female mice generated female mice with $100 \%$ penetrance of highly aggressive and metastatic endometrioid ovarian cancer at 12 weeks. Interestingly, this mouse model has ovarian endometriosis-like lesions with either addition of oncogenic Kras ${ }^{G 12 D}$ or deletion of Pten alone, but only results in endometrioid ovarian cancer when both Pten and Kras ${ }^{G 12 D}$ are simultaneously mutated [162].

A mouse model targeting both Pten and Apc resulted in endometrioid ovarian cancer with high penetrance and metastatic disease [161]. Unfortunately, this conditional knockout $\left(A d^{C r e}\right)$ did not result in endometriosis, which may be due to the early (6-week post-injection) tumor development [161]. Another model of endometrioid carcinoma in mice utilized a double conditional knockout of Pten and Arid1 $a$ and intrabursal $A d^{C r e}$ injection to show a progression of ovarian surface epithelium hyperplasia, endometrioid carcinoma, and finally poorly differentiated carcinoma [158]. The well-differentiated endometrioid carcinoma was confined to the ovaries, suggesting the place of origin, while the undifferentiated tumors had metastasized into the peritoneal cavity [158]. Guan et al. hypothesizes that ARID1A plays a role in both tumor initiation and progression but requires the collaborative second hit of Pten to produce tumors [158]. Although the hyperplasia was not linked to endometriosis in these mice, it does speak to an environment of uncontrolled cellular proliferation giving rise to endometrioid ovarian cancer when left untreated.

High nuclear $\beta$-catenin levels have uniquely been found in endometrioid ovarian cancer from women, where this nuclear accumulation leads to activation of the WNT pathway [149]. Gain-of-function deletion of exon 3 of $C t n n b 1$ leads to stable $\beta$-catenin expression in mice [175]. Amhr $2^{\mathrm{Cre}} \mathrm{Ctnnb1} 1^{\mathrm{f} / \mathrm{f}}$ female mice have aggressive endometrioid ovarian cancers with $100 \%$ penetrance by 6 months. Addition of Pten deletion to this model allows for tumors that are even more aggressive by 6 weeks [165]. Similar to deletion of exon 3 of Ctnnb1, deletion of Apc leads to stable $\beta$-catenin and WNT signaling activation [149]. Only with deletion of Pten did mice develop ovarian tumors [161]. To model the progression of type I tumors to the more aggressive type II tumors, Wu et al. (2013) added Pik3ca ${ }^{E 545 K /+}$ to $A p c^{f / f}$ Pten $/ f$ mice with $\mathrm{Ad}^{\mathrm{Cre}}$ and showed peritoneal and lung metastasis [167].

While these models used $\mathrm{Amhr} 2^{\mathrm{Cre}}$ or $\mathrm{Ad}^{\mathrm{Cre}}$ to focus genetic changes in the ovarian surface epithelium, other studies have created conditional genetic changes in the oviduct. When Apc and Pten were concurrently deleted in the fallopian tube using Ovgp $1^{\mathrm{Cre}}$, endometrioid tumors of the ovaries developed in 10 of 15 mice, with $50 \%$ of those resulting in metastasis to the lungs or omentum [146]. Deletion of Pten in the fallopian tube by $\mathrm{Pax}^{\mathrm{Cre}}$ also resulted in endometrioid tumors. Specifically, $75 \%$ of female mice developed primary tumors in the fallopian tube by 7 months, and $75 \%$ of tumor-burdened mice had metastasis to the ovaries [147]. Deletion of $\mathrm{Apc}$ with $\mathrm{Pgr} \mathrm{Cre}$ female mice revealed tumors in both the oviduct and ovaries. Specifically, 25 of 40 female mice developed 
endometrioid oviductal tumors, one of 43 developed granulosa cell tumors, and 12 of 43 developed endometrioid ovarian tumors. While these female mice had simple ovarian cysts, the authors did not specifically denominate them as endometriosis [166]. Taken together, these mouse models suggest that the oviduct and/or the ovary may be involved in endometrioid cancer development in the mouse.

\subsubsection{Low-Grade Serous Ovarian Cancer}

Addition of oncogenic Kras (Kras ${ }^{G 12 D}$ ) with either Amhr2 $2^{C r e}$ or Cyp19Cre resulted in ovaries with abnormal follicles, which were non-tumorigenic but also non-mitotic and non-apoptotic [145]. Deletion of Pten using Amhr $2^{C r e}$ did result in increased proliferation and increased cell survival of ovarian surface epithelium [163]. However, the loss of the tumor suppressor Pten alone is not tumorigenic in somatic cells of the ovary. When Pten is deleted in the context of oncogenic Kras with $\mathrm{Amhr} 2^{\mathrm{Cre}}$, there is development of low-grade serous papillary cystadenocarcinoma [163]. Although no endometriosis was noted, these mice were shown to have ovarian surface epithelium hyperplasia and abnormal follicle-derived ovarian lesions. Mullany et al. continued work on the Kras ${ }^{G 12 D}$;Pten f/f;Amhr2 ${ }^{\mathrm{Cre}}$ mice and showed that ovarian surface epithelium cells, removed from mutant mice prior to tumor formation, developed into tumors when grown in soft agar [143]. This key result suggests that Kras and Pte// play a significant role in the development of tumors in the ovarian surface epithelium, and the genetic mutations are the primary driver, since tumor formation occurred even outside of the ovarian microenvironment [143].

\subsection{Other Models}

\subsubsection{Immortalized Cell Lines}

Immortalized human ovarian cancer cell lines have been widely used for studying molecular mechanisms of ovarian cancer. Ovarian cancer cell lines are used to study cancer biology, connecting genetic and epigenetic alterations to cancer development, progression, and drug response. Importantly, ovarian cancer cell lines have been developed from different histological and molecular subtypes of ovarian cancer. Unfortunately, molecular characterization has revealed that common ovarian cancer cell lines (i.e., SKOV3, HEYA8) do not molecularly represent the histology of tumor of origin. The number of cell lines derived from either endometrioid or clear cell ovarian cancers is more limited than high-grade serous cell lines. However, molecular profiling, including attention to gene mutations common in these endometriosis-associated ovarian cancers (i.e., ARID1A, PIK3CA, CTNNB1, PTEN, and KRAS) and mutations common in high-grade serous (i.e., TP53), have allowed better molecular and biological distinction [176-182]. Table 4 shows the common endometrioid and clear-cell ovarian cancer cell lines, including lines that were not derived from endometriosis-associated ovarian cancers, but which may molecularly represent non-high grade serous cell lines. Even fewer cell endometriotic cell lines exist, with $12 Z$ cells being the only widely shared epithelial-like endometriosis immortalized cell line [183]. For rigor and reproducibility, additional well-characterized endometriotic cell lines and possibly ovarian cancer cell lines derived from women with endometriosis need to be created. 
Table 4. Endometriosis and endometriosis-associated ovarian cancer cell lines.

\begin{tabular}{|c|c|c|c|c|c|}
\hline Cell Line & Original Derivation & $\begin{array}{c}\text { Putative Histotype by } \\
\text { Molecular Studies }\end{array}$ & Genetic Mutations & Genetic Gains & Ref. \\
\hline $11 Z$ & Red peritoneal endometriotic lesion & Benign & Unknown & Unknown & [183] \\
\hline $12 Z$ & Red peritoneal endometriotic lesion & Benign (epithelial-like) & Unknown & Unknown & [183] \\
\hline EEC16 & $\begin{array}{l}\text { Benign endometriotic lesion } \\
\text { (epithelial-like) }\end{array}$ & Benign & Unknown & Unknown & [184] \\
\hline EMosis-CC/TERT & $\begin{array}{c}\text { Benign endometriotic lesion } \\
\text { (epithelial-like) }\end{array}$ & Benign & Unknown & Unknown & [185] \\
\hline $22 B$ & $\begin{array}{l}\text { Red peritoneal endometriotic lesion } \\
\text { (Stromal/fibroblast-like) }\end{array}$ & Benign & Unknown & Unknown & [183] \\
\hline $\begin{array}{l}\text { Hs 832(C).T } \\
\text { (CRL-7566) }\end{array}$ & Benign endometriotic ovarian cyst & Benign & Unknown & Unknown & ATCC \\
\hline OVTOKO & Clear-cell (spleen metastasis) & Clear-cell & None & $\begin{array}{c}\text { ERRB2, HNF1B, MET, } \\
\text { PPM1D, STAT3, TP53, YAP1, } \\
\text { ZNF217, CDKN2A, CDKN2B }\end{array}$ & {$[177-179,182]$} \\
\hline OVMANA & Clear-cell (primary tumor) & Clear-cell & BRCA2, PIK3CA, ARID1A & $\begin{array}{c}\text { ARID1A, MET, PPM1D, } \\
\text { TP53, ZNF217 }\end{array}$ & {$[178,179,182,186]$} \\
\hline TOV21G & Clear-cell (primary tumor) & Clear-cell & $\begin{array}{c}\text { KRAS, PTEN, PIK3CA, } \\
\text { CTNNB1, ARID1A, TPX2 }\end{array}$ & & {$[178-182,187]$} \\
\hline RMG-1 & Clear-cell (ascites) & Clear-cell & TP53* & $E R B B 2$ & {$[178,179,182,188]$} \\
\hline RMG-2 & Clear-cell & Clear-cell & PPP2R1A, ARID1A & $\begin{array}{c}\text { ERBB2, HNF1B, MET, } \\
\text { PIK3CA, PPM1D, STAT3, } \\
\text { ZNF217, CDKN2A, CDKN2B }\end{array}$ & [179] \\
\hline OCC1 & Clear-cell & Clear-cell & & & [189] \\
\hline JHOC-5 & Clear-cell (pelvic metastasis) & Clear-cell & & $\begin{array}{c}\text { ARID1A, ERBB2, HNF1B, } \\
\text { MET, PIK3CA, PPM1D, } \\
\text { STAT2, ZNF217, } \\
\text { CDKN2A, CDKN2B }\end{array}$ & {$[178,179,182,190]$} \\
\hline JHOC-7 & Clear-cell & Clear-cell & PIK3CA & $\begin{array}{l}\text { ARID1A, HNF1B, PIK3CA, } \\
\text { PPM1D, STAT3, ZNF217 }\end{array}$ & [179] \\
\hline
\end{tabular}


Table 4. Cont

\begin{tabular}{|c|c|c|c|c|c|}
\hline Cell Line & Original Derivation & $\begin{array}{l}\text { Putative Histotype by } \\
\text { Molecular Studies }\end{array}$ & Genetic Mutations & Genetic Gains & Ref. \\
\hline JHOC-9 & Clear-cell & Clear-cell & PTEN, ARID1A & HNF1B, ZNF217 & [179] \\
\hline ES2 & $\begin{array}{l}\text { Poorly differentiated clear-cell } \\
\text { (primary tumor) }\end{array}$ & Endometrioid/Clear-cell & $B R A F, T P 53, A P C, M Y C$ & & {$[178-182,191]$} \\
\hline OVISE & Clear-cell (pelvic metastasis) & Endometrioid/Clear-cell & ARID1A & & {$[177-179,182]$} \\
\hline OVSAYO & Clear-cell & Serous & TP53 & & [179] \\
\hline TOV112D & Endometrioid (primary tumor) & Endometrioid & CTNNB1, TP53 & & {$[179-182,187]$} \\
\hline OVK18 & Endometrioid (ascites) & Endometrioid & $\begin{array}{c}\text { TP53, PTEN, KRAS, } \\
\text { ARID1A }\end{array}$ & & {$[178,182,192]$} \\
\hline SNU-251 & Endometrioid & Endometrioid & $B R C A 1$ & & [193] \\
\hline 2008 & Endometrioid & Atypical non-serous & TP53 & & [179] \\
\hline IGROV1 & $\begin{array}{l}\text { Endometrioid with serous/clear cell } \\
\text { (primary tumor) }\end{array}$ & Endometrioid/Clear-cell & $\begin{array}{c}\text { PTEN, TP53, ARID1A, } \\
\text { BRCA1, BRCA2, PIK3CA, } \\
\text { TPX2 }\end{array}$ & & {$[178-180,182,194]$} \\
\hline $59 \mathrm{M}$ & Endometrioid with clear cell (ascites) & Endometrioid/Clear-cell & TP53 & $M Y C$ & {$[178,180,182,193,195]$} \\
\hline COV362 & Endometrioid (pleural effusion) & Serous & $\begin{array}{c}\text { TP53, BRCA1, RB1 * EGFR, } \\
A P C\end{array}$ & $M Y C$ & {$[178,180,182,196]$} \\
\hline A2780 & Unknown adenocarcinoma & Endometrioid & $\begin{array}{c}\text { PTEN, ARID1A, PIK3CA, } \\
\text { BRAF }\end{array}$ & & [178-182,197] \\
\hline HEYA8 & $\begin{array}{l}\text { Moderately differentiated papillary } \\
\text { serous (peritoneal metastasis) }\end{array}$ & Unlikely serous & $K R A S, B R A F$ & & {$[178,179,182,198]$} \\
\hline SKOV3 & $\begin{array}{l}\text { Well differentiated, adenocarcinoma } \\
\text { (ascites) }\end{array}$ & Endometrioid/Clear-cell & PIK3CA, ARID1A & $E R B B 2$ & [178-182,199] \\
\hline
\end{tabular}

${ }^{*}$ Homozygous deletion 


\subsubsection{Xenograft Models}

Implantation of immortalized human cell lines typically requires immunocompromised mice. A Japanese group created telomerase transformed endometriosis epithelial cell lines and confirmed cellular growth, steroid hormone response, and lack of malignant transformation in nude mice [185]. Further, these cells have been used in xenograft models to study treatment effects of small molecular inhibitors in endometriosis $[104,200]$. However, limited distribution outside Japan has restricted the use of these cells for studies of endometriosis-associated ovarian cancers. A similarly developed endometriotic epithelial cell line (EEC16) does not grow in SCID mice [184].

In terms of the endometriotic tumor microenvironment, Komiyama et al. placed normal endometrium of women without endometriosis into SCID mice. RMG-1 cells, a clear-cell ovarian cancer cell line, were grown in mice then transplanted into mice with or without endometrial implants. Although the tumors weighed less when grown with endometrium, proliferation was significantly higher in mice with transplanted endometrium. Additionally, these tumors expressed high levels of TGF $\beta$ and IL6. Addition of normal human endometrium changed the xenograft model to a more endometriotic microenvironment [201].

\subsubsection{Three Dimensional (3D) and Co-Culture Models}

Immortalized cell lines in monolayer two-dimensional (2D) culture fail to recapitulate the complexity of tumor tissue. Tumors are three-dimensional (3D) structures, surrounded by other cell types and a unique extracellular matrix (ECM) that is biologically optimized for growth of each cell type [202]. To recapitulate this for in vitro model systems, immortalized cell lines can be grown in Matrigel, ultra-low-adhesive plates, or a hanging drop. Using these methods, many immortalized cell lines will form 3D spheroids. Three-dimensional spheroid models can be highly instructive towards the understanding of current drug resistance and new therapeutics because they better mimic the way 3D tumors or de novo spheroids interact with the surrounding microenvironment. Specifically, the architecture of spheroids results in non-heterogeneity of nutrient and drug penetration, which can cause differential responses to varying layers of the spheroid. For example, Lee et al. compared 31 ovarian cancer cell lines in both 2D monolayer and 3D spheroids to primary tumors. Three-dimensional spheroids showed slower rates of proliferation and decreased drug sensitivity than the same cells grown in 2D [202]. Additionally, these 3D spheroids mimicked histological characteristics of primary tumors. Although the authors did not perform genome-wide transcriptomic analysis, candidate biomarkers such as mucin 16, cell surface associated (CA125), Wilms Tumor 1 (WT1), estrogen receptor, Paired box gene 8 (PAX8), and $\beta$-catenin were examined by IHC on a tissue microarray composed of 2D and 3D samples. The expression of these biomarkers correlated well with expression in primary tumors [202]. These data suggest that 3D spheroid models alter the microenvironment in a potentially more biological way compared to other in vitro systems. Additionally, Lal-Nag et al. used high-throughput screening to test multiple oncological drugs against the HEYA8 cell line. The cells responded differently to various drugs if they were grown in monolayer, in the process of forming spheroids, or already in pre-formed spheroids. This work establishes that the dimensionality of ovarian cancer cells plays a role in how they respond to their environment [203]. Similarly, Chowwanadisai et al. created cisplatin-resistant ovarian cancer spheroids by treating cells with sub-threshold doses of cisplatin, which resulted in a mesenchymal-enriched gene expression signature [204]. While molecular changes within spheroids may play a role in chemotherapy resistance, size of spheroids, similar to remaining disease after debulking surgery, plays a role in response. Tanenbaum et al. [205] showed that small spheroids treated with either short-term high-dose or prolonged low-dose cisplatin underwent significant shrinkage. Importantly, large spheroids preferentially responded to short-term high doses of cisplatin [205]. The investigators did not explore if the remaining cells became chemotherapy-resistant [205]. Although immortalized cell lines from endometrioid or clear cell ovarian cancers have not been extensively tested in 3D culture, we anticipate that they would behave similarly. 
In addition to single cell types within 3D spheroids, co-culture systems can be useful. For example, endometrial epithelial cells are inhibited at a rate of $65-80 \%$ when grown in co-culture with endometrial stromal cells, highlighting the need for complex co-culture models [206]. Additionally, co-culture models of epithelial and stromal endometriosis cells show that stromal cells are responsible for metabolism of iron. The authors hypothesize that storage of iron by stromal cells is protective against malignant transformation of epithelial cells. Specifically, a lack of stromal cells and an abundance of epithelial cells, which cannot metabolize iron, leads to oxidative damage and oncogenic change [207]. This hypothesis fits with data from Anglesio et al. showing tumorigenic mutations in KRAS in epithelial cells of endometriosis but not stromal cells [27]. Similarly, co-culture of macrophages with endometriotic epithelial or endometriotic stromal cells leads to an increase in invasion that is more robust in epithelial than stromal cells [208]. Three-dimensional organoids made from endometrium and decidua have been developed simultaneously by two independent laboratories and represent promising models for in vitro study $[209,210]$. Development of additional endometriotic tumor microenvironment models are needed to study ovarian cancer cells within spheroids, 3D organoids, or co-culture systems.

\section{Future of Precision Therapy for/or Prevention of Ovarian Cancer}

Endometriosis is a known risk factor for ovarian cancer [41]. However, early treatment of endometriosis represents a known prevention strategy for ovarian cancer. For example, a woman on oral contraceptive therapy has a more robust protection against ovarian cancer if she has endometriosis than if she does not [120]. While treatment of endometriosis with contraceptives is effective, women desiring fertility do not enjoy the side of effects of contraception, and when medical management is stopped, $73 \%$ of women have return of symptoms. Additionally, surgical treatment of endometriosis with removal of one or both ovaries results in significant decrease in ovarian cancer risk. However, $55 \%$ of women undergoing local resection of endometriosis will have at least one more surgery over the course of seven years [211,212]. Morbidity associated with multiple operations makes selection of timing for endometriosis surgery important in pre-menopausal women. New treatments for endometriosis are needed. Importantly, discovery of new treatments for endometriosis should be a priority for ovarian cancer funding agencies as these therapies may lead to prevention of ovarian cancer.

In terms of therapy highlighting the importance of the molecular signaling between cells within tumors, Mok et al. used a systems biology approach to study individual cell types. Machine learning with large databases of drugs and molecular effects highlighted an FDA-approved drug for potential targeted treatment. While this study used high-grade serous ovarian tumors, it brings forward the importance of non-epithelial ovarian cancer cells in cancer treatment [213]. Importantly, the study focused on TGF $\beta$ signaling pathways [213]. Endometriosis also has dysregulated TGF $\beta$ signaling pathways [92]. Similar treatment of endometriosis may prevent ovarian cancer.

\section{Conclusions}

The Gynecologic Cancers Steering Committee of the National Institutes of Health (NIH) proposed strategic priorities for ovarian cancer. These research priorities focus on discovery of biomarkers, identification of cancer subsets to drive treatment recommendations, immunotherapy, combination therapies, and manipulation of the host-tumor microenvironment. While these priorities are not specific for a particular histotype, they are highly applicable to both the more common high-grade serous and less common endometriosis-associated ovarian cancers and warrant further study in endometriosis-associated ovarian cancer models.

Supplementary Materials: The following are available online at http:/ /www.mdpi.com/2072-6694/10/8/261/s1, Table S1: Dysregulated miRNAs in ovarian endometrioid and clear-cell adenocarcinoma and endometriosis.

Author Contributions: J.R.H.W., X.W. and S.M.H. constructed the outline of the review, synthesized and referenced the works included, and wrote the manuscript. 
Funding: This work was supported by NIH/NCI R03CA19127, Rivkin Center for Ovarian Cancer Pilot Award.

Conflicts of Interest: The authors declare no conflict of interest.

\section{References}

1. Bulun, S.E. Endometriosis. N. Engl. J. Med. 2009, 360, 268-279. [CrossRef] [PubMed]

2. Giudice, L.C.; Kao, L.C. Endometriosis. Lancet 2004, 364, 1789-1799. [CrossRef]

3. Buck Louis, G.M.; Hediger, M.L.; Peterson, C.M.; Croughan, M.; Sundaram, R.; Stanford, J.; Chen, Z.; Fujimoto, V.Y.; Varner, M.W.; Trumble, A.; et al. Incidence of endometriosis by study population and diagnostic method: The endo study. Fertil. Steril. 2011, 96, 360-365. [CrossRef] [PubMed]

4. DiVasta, A.D.; Vitonis, A.F.; Laufer, M.R.; Missmer, S.A. Spectrum of symptoms in women diagnosed with endometriosis during adolescence vs. adulthood. Am. J. Obstet. Gynecol. 2018, 218, 324.e1-324.e11. [CrossRef] [PubMed]

5. Aerts, L.; Grangier, L.; Streuli, I.; Dallenbach, P.; Marci, R.; Wenger, J.M.; Pluchino, N. Psychosocial impact of endometriosis: From co-morbidity to intervention. Best Pract. Res. Clin. Obstet. Gynaecol. 2018. [CrossRef] [PubMed]

6. Pearce, C.L.; Stram, D.O.; Ness, R.B.; Stram, D.A.; Roman, L.D.; Templeman, C.; Lee, A.W.; Menon, U.; Fasching, P.A.; McAlpine, J.N.; et al. Population distribution of lifetime risk of ovarian cancer in the united states. Cancer Epidemiol. Biomark. Prev. 2015, 24, 671-676. [CrossRef] [PubMed]

7. Pearce, C.L.; Templeman, C.; Rossing, M.A.; Lee, A.; Near, A.M.; Webb, P.M.; Nagle, C.M.; Doherty, J.A.; Cushing-Haugen, K.L.; Wicklund, K.G.; et al. Association between endometriosis and risk of histological subtypes of ovarian cancer: A pooled analysis of case-control studies. Lancet Oncol. 2012, 13, 385-394. [CrossRef]

8. Nagle, C.M.; Olsen, C.M.; Webb, P.M.; Jordan, S.J.; Whiteman, D.C.; Green, A.C.; Australian Cancer Study Group; Australian Ovarian Cancer Study Group. Endometrioid and clear cell ovarian cancers: A comparative analysis of risk factors. Eur. J. Cancer 2008, 44, 2477-2484. [CrossRef] [PubMed]

9. Rossing, M.A.; Cushing-Haugen, K.L.; Wicklund, K.G.; Doherty, J.A.; Weiss, N.S. Risk of epithelial ovarian cancer in relation to benign ovarian conditions and ovarian surgery. Cancer Causes Control 2008, 19, 1357-1364. [CrossRef] [PubMed]

10. Brinton, L.A.; Gridley, G.; Persson, I.; Baron, J.; Bergqvist, A. Cancer risk after a hospital discharge diagnosis of endometriosis. Am. J. Obstet. Gynecol. 1997, 176, 572-579. [CrossRef]

11. Kobayashi, H.; Sumimoto, K.; Moniwa, N.; Imai, M.; Takakura, K.; Kuromaki, T.; Morioka, E.; Arisawa, K.; Terao, T. Risk of devloping ovarian cancer among women with ovarian endometrioma: A cohort study in shizuoka, Japan. Int. J. Cancer 2007, 17, 37-43. [CrossRef] [PubMed]

12. Somigliana, E.; Vigano, P.; Parazzini, F.; Stoppelli, S.; Giambattista, E.; Vercellini, P. Association between endometriosis and cancer: A comprehensive review and a critical analysis of clinical and epidemiological evidence. Gynecol. Oncol. 2006, 101, 331-341. [CrossRef] [PubMed]

13. Siegel, R.L.; Miller, K.D.; Jemal, A. Cancer statistics, 2018. CA Cancer J. Clin. 2018, 68, 7-30. [CrossRef] [PubMed]

14. Kurman, R.J.; Shih Ie, M. The dualistic model of ovarian carcinogenesis: Revisited, revised, and expanded. Am. J. Pathol. 2016, 186, 733-747. [CrossRef] [PubMed]

15. Reid, B.M.; Permuth, J.B.; Sellers, T.A. Epidemiology of ovarian cancer: A review. Cancer Biol. Med. 2017, 14, 9-32. [PubMed]

16. Prat, J. Pathology of borderline and invasive cancers. Best Pract. Res. Clin. Obstet. Gynaecol. 2017, 41, 15-30. [CrossRef] [PubMed]

17. Lu, J.; Tao, X.; Zhou, J.; Lu, Y.; Wang, Z.; Liu, H.; Xu, C. Improved clinical outcomes of patients with ovarian carcinoma arising in endometriosis. Oncotarget 2017, 8, 5843-5852. [CrossRef] [PubMed]

18. Dinkelspiel, H.E.; Matrai, C.; Pauk, S.; Pierre-Louis, A.; Chiu, Y.L.; Gupta, D.; Caputo, T.; Ellenson, L.H.; Holcomb, K. Does the presence of endometriosis affect prognosis of ovarian cancer? Cancer Investig. 2016, 34, 148-154. [CrossRef] [PubMed]

19. McMeekin, D.S.; Burger, R.A.; Manetta, A.; DiSaia, P.; Berman, M.L. Endometrioid adenocarcinoma of the ovary and its relationship to endometriosis. Gynecol. Oncol. 1995, 59, 81-86. [CrossRef] [PubMed] 
20. Melin, A.; Lundholm, C.; Malki, N.; Swahn, M.L.; Sparen, P.; Bergqvist, A. Endometriosis as a prognostic factor for cancer survival. Int. J. Cancer 2011, 129, 948-955. [CrossRef] [PubMed]

21. Quirk, J.T.; Natarajan, N.; Mettlin, C.J. Age-specific ovarian cancer incidence rate patterns in the united states. Gynecol. Oncol. 2005, 99, 248-250. [CrossRef] [PubMed]

22. Gershenson, D.M. Treatment of ovarian cancer in young women. Clin. Obstet. Gynecol. 2012, 55, 65-74. [CrossRef] [PubMed]

23. Storey, D.J.; Rush, R.; Stewart, M.; Rye, T.; Al-Nafussi, A.; Williams, A.R.; Smyth, J.F.; Gabra, H. Endometrioid epithelial ovarian cancer: 20 years of prospectively collected data from a single center. Cancer 2008, 112, 2211-2220. [CrossRef] [PubMed]

24. Noli, S.; Cipriani, S.; Scarfone, G.; Villa, A.; Grossi, E.; Monti, E.; Vercellini, P.; Parazzini, F. Long term survival of ovarian endometriosis associated clear cell and endometrioid ovarian cancers. Int. J. Gynecol. Cancer 2013, 23, 244-248. [CrossRef] [PubMed]

25. Ahmed, A.A.; Becker, C.M.; Bast, R.C., Jr. The origin of ovarian cancer. BJOG 2012, 119, 134-136. [CrossRef] [PubMed]

26. Cochrane, D.R.; Tessier-Cloutier, B.; Lawrence, K.M.; Nazeran, T.; Karnezis, A.N.; Salamanca, C.; Cheng, A.S.; McAlpine, J.N.; Hoang, L.N.; Gilks, C.B.; et al. Clear cell and endometrioid carcinomas: Are their differences attributable to distinct cells of origin? J. Pathol. 2017, 243, 26-36. [CrossRef] [PubMed]

27. Anglesio, M.S.; Papadopoulos, N.; Ayhan, A.; Nazeran, T.M.; Noe, M.; Horlings, H.M.; Lum, A.; Jones, S.; Senz, J.; Seckin, T.; et al. Cancer-associated mutations in endometriosis without cancer. N. Engl. J. Med. 2017, 376, 1835-1848. [CrossRef] [PubMed]

28. Chui, M.H.; Wang, T.L.; Shih, I.M. Endometriosis: Benign, malignant, or something in between? Oncotarget 2017, 8, 78263-78264. [CrossRef] [PubMed]

29. Lac, V.; Huntsman, D.G. Distinct developmental trajectories of endometriotic epithelium and stroma: Implications for the origins of endometriosis. J. Pathol. 2018. [CrossRef] [PubMed]

30. Wiegand, K.C.; Shah, S.P.; Al-Agha, O.M.; Zhao, Y.; Tse, K.; Zeng, T.; Senz, J.; McConechy, M.K.; Anglesio, M.S.; Kalloger, S.E.; et al. Arid1a mutations in endometriosis-associated ovarian carcinomas. N. Engl. J. Med. 2010, 363, 1532-1543. [CrossRef] [PubMed]

31. Sato, N.; Tsunoda, H.; Nishida, M.; Morishita, Y.; Takimoto, Y.; Kubo, T.; Noguchi, M. Loss of heterozygosity on 10q23.3 and mutation of the tumor suppressor gene Pten in benign endometrial cyst of the ovary: Possible sequence progression from benign endometrial cyst to endometrioid carcinoma and clear cell carcinoma of the ovary. Cancer Res. 2000, 60, 7052-7056. [PubMed]

32. Yamamoto, S.; Tsuda, H.; Takano, M.; Tamai, S.; Matsubara, O. Loss of arid1a protein expression occurs as an early event in ovarian clear-cell carcinoma development and frequently coexists with PIK3CA mutations. Mod. Pathol. 2012, 25, 615-624. [CrossRef] [PubMed]

33. Stewart, C.J.; Leung, Y.; Walsh, M.D.; Walters, R.J.; Young, J.P.; Buchanan, D.D. Kras mutations in ovarian low-grade endometrioid adenocarcinoma: Association with concurrent endometriosis. Hum. Pathol. 2012, 43, 1177-1183. [CrossRef] [PubMed]

34. Zou, Y.; Zhou, J.Y.; Guo, J.B.; Wang, L.Q.; Luo, Y.; Zhang, Z.Y.; Liu, F.Y.; Tan, J.; Wang, F.; Huang, O.P. The presence of kras, ppp2r1a and arid1a mutations in 101 Chinese samples with ovarian endometriosis. Mutat. Res. 2018, 809, 1-5. [CrossRef] [PubMed]

35. Wiegand, K.C.; Lee, A.F.; Al-Agha, O.M.; Chow, C.; Kalloger, S.E.; Scott, D.W.; Steidl, C.; Wiseman, S.M.; Gascoyne, R.D.; Gilks, B.; et al. Loss of baf250a (arid1a) is frequent in high-grade endometrial carcinomas. J. Pathol. 2011, 224, 328-333. [CrossRef] [PubMed]

36. Yamamoto, S.; Tsuda, H.; Takano, M.; Tamai, S.; Matsubara, O. Pik3ca mutations and loss of arid1a protein expression are early events in the development of cystic ovarian clear cell adenocarcinoma. Virchows Arch. 2012, 460, 77-87. [CrossRef] [PubMed]

37. Samartzis, E.P.; Samartzis, N.; Noske, A.; Fedier, A.; Caduff, R.; Dedes, K.J.; Fink, D.; Imesch, P. Loss of arid1a/baf250a-expression in endometriosis: A biomarker for risk of carcinogenic transformation? Mod. Pathol. 2012, 25, 885-892. [CrossRef] [PubMed]

38. Ayhan, A.; Mao, T.L.; Seckin, T.; Wu, C.H.; Guan, B.; Ogawa, H.; Futagami, M.; Mizukami, H.; Yokoyama, Y.; Kurman, R.J.; et al. Loss of arid1a expression is an early molecular event in tumor progression from ovarian endometriotic cyst to clear cell and endometrioid carcinoma. Int. J. Gynecol. Cancer 2012, 22, 1310-1315. [CrossRef] [PubMed] 
39. Xiao, W.; Awadallah, A.; Xin, W. Loss of arid1a/baf250a expression in ovarian endometriosis and clear cell carcinoma. Int. J. Clin. Exp. Pathol. 2012, 5, 642-650. [PubMed]

40. Anglesio, M.S.; Yong, P.J. Endometriosis-associated ovarian cancers. Clin. Obstet. Gynecol. 2017, 60, 711-727. [CrossRef] [PubMed]

41. Vercellini, P.; Vigano, P.; Buggio, L.; Makieva, S.; Scarfone, G.; Cribiu, F.M.; Parazzini, F.; Somigliana, E. Perimenopausal management of ovarian endometriosis and associated cancer risk: When is medical or surgical treatment indicated? Best Pract. Res. Clin. Obstet. Gynaecol. 2018. [CrossRef] [PubMed]

42. Friedlander, M.L.; Russell, K.; Millis, S.; Gatalica, Z.; Bender, R.; Voss, A. Molecular profiling of clear cell ovarian cancers: Identifying potential treatment targets for clinical trials. Int. J. Gynecol. Cancer 2016, 26, 648-654. [CrossRef] [PubMed]

43. Ishikawa, M.; Nakayama, K.; Nakamura, K.; Ono, R.; Sanuki, K.; Yamashita, H.; Ishibashi, T.; Minamoto, T.; Iida, K.; Razia, S.; et al. Affinity-purified DNA-based mutation profiles of endometriosis-related ovarian neoplasms in Japanese patients. Oncotarget 2018, 9, 14754-14763. [CrossRef] [PubMed]

44. Jones, S.; Wang, T.L.; Shih Ie, M.; Mao, T.L.; Nakayama, K.; Roden, R.; Glas, R.; Slamon, D.; Diaz, L.A., Jr.; Vogelstein, B.; et al. Frequent mutations of chromatin remodeling gene arid1a in ovarian clear cell carcinoma. Science 2010, 330, 228-231. [CrossRef] [PubMed]

45. Shibuya, Y.; Tokunaga, H.; Saito, S.; Shimokawa, K.; Katsuoka, F.; Bin, L.; Kojima, K.; Nagasaki, M.; Yamamoto, M.; Yaegashi, N.; et al. Identification of somatic genetic alterations in ovarian clear cell carcinoma with next generation sequencing. Genes Chromosom. Cancer 2018, 57, 51-60. [CrossRef] [PubMed]

46. Grisham, R.N.; Iyer, G.; Garg, K.; DeLair, D.; Hyman, D.M.; Zhou, Q.; Iasonos, A.; Berger, M.F.; Dao, F.; Spriggs, D.R. Braf mutation is associated with early stage disease and improved outcome in patients with low-grade serous ovarian cancer. Cancer 2013, 119, 548-554. [CrossRef] [PubMed]

47. Sieben, N.L.; Macropoulos, P.; Roemen, G.M.; Kolkman-Uljee, S.M.; Jan Fleuren, G.; Houmadi, R.; Diss, T.; Warren, B.; Al Adnani, M.; De Goeij, A.P.; et al. In ovarian neoplasms, braf, but not kras, mutations are restricted to low-grade serous tumours. J. Pathol. 2004, 202, 336-340. [CrossRef] [PubMed]

48. Singer, G.; Oldt, R., 3rd; Cohen, Y.; Wang, B.G.; Sidransky, D.; Kurman, R.J.; Shih Ie, M. Mutations in BRAF and KRAS characterize the development of low-grade ovarian serous carcinoma. J. Natl. Cancer Inst. 2003, 95, 484-486. [CrossRef] [PubMed]

49. Lv, X.; Wang, D.; Ma, Y.; Long, Z. Analysis of the oncogene braf mutation and the correlation of the expression of wild-type BRAF and CREB1 in endometriosis. Int. J. Mol. Med. 2018, 41, 1349-1356. [CrossRef] [PubMed]

50. Saare, M.; Krigul, K.L.; Laisk-Podar, T.; Ponandai-Srinivasan, S.; Rahmioglu, N.; Lalit Kumar, P.G.; Zondervan, K.; Salumets, A.; Peters, M. DNA methylation alterations-potential cause of endometriosis pathogenesis or a reflection of tissue heterogeneity? Biol. Reprod. 2018. [CrossRef] [PubMed]

51. He, J.; Chang, W.; Feng, C.; Cui, M.; Xu, T. Endometriosis malignant transformation: Epigenetics as a probable mechanism in ovarian tumorigenesis. Int. J. Genom. 2018, 2018, 1465348. [CrossRef] [PubMed]

52. Roca, F.J.; Loomans, H.A.; Wittman, A.T.; Creighton, C.J.; Hawkins, S.M. Ten-eleven translocation genes are downregulated in endometriosis. Curr. Mol. Med. 2016, 16, 288-298. [CrossRef] [PubMed]

53. Nothnick, W.B. MicroRNAs and endometriosis: Distinguishing drivers from passengers in disease pathogenesis. Semin. Reprod. Med. 2017, 35, 173-180. [CrossRef] [PubMed]

54. Logan, M.; Hawkins, S.M. Role of microRNAs in cancers of the female reproductive tract: Insights from recent clinical and experimental discovery studies. Clin. Sci. (Lond. Engl. 1979) 2015, 128, 153-180. [CrossRef] [PubMed]

55. Wang, X.; Ivan, M.; Hawkins, S.M. The role of microRNA molecules and microRNA-regulating machinery in the pathogenesis and progression of epithelial ovarian cancer. Gynecol. Oncol. 2017, 147, 481-487. [CrossRef] [PubMed]

56. Machado-Linde, F.; Sanchez-Ferrer, M.L.; Cascales, P.; Torroba, A.; Orozco, R.; Silva Sanchez, Y.; Nieto, A.; Fiol, G. Prevalence of endometriosis in epithelial ovarian cancer. Analysis of the associated clinical features and study on molecular mechanisms involved in the possible causality. Eur. J. Gynaecol. Oncol. 2015, 36, 21-24. [PubMed]

57. Stamp, J.P.; Gilks, C.B.; Wesseling, M.; Eshragh, S.; Ceballos, K.; Anglesio, M.S.; Kwon, J.S.; Tone, A.; Huntsman, D.G.; Carey, M.S. Baf250a expression in atypical endometriosis and endometriosis-associated ovarian cancer. Int. J. Gynecol. Cancer 2016, 26, 825-832. [CrossRef] [PubMed] 
58. Van Gorp, T.; Amant, F.; Neven, P.; Vergote, I.; Moerman, P. Endometriosis and the development of malignant tumours of the pelvis. A review of literature. Best Pract. Res. Clin. Obstet. Gynaecol. 2004, 18, 349-371. [CrossRef] [PubMed]

59. Fukunaga, M.; Nomura, K.; Ishikawa, E.; Ushigome, S. Ovarian atypical endometriosis: Its close association with malignant epithelial tumours. Histopathology 1997, 30, 249-255. [CrossRef] [PubMed]

60. Banz, C.; Ungethuem, U.; Kuban, R.J.; Diedrich, K.; Lengyel, E.; Hornung, D. The molecular signature of endometriosis-associated endometrioid ovarian cancer differs significantly from endometriosis-independent endometrioid ovarian cancer. Fertil. Steril. 2010, 94, 1212-1217. [CrossRef] [PubMed]

61. Zhang, C.; Wang, X.; Anaya, Y.; Parodi, L.; Chen, L.; Anderson, M.L.; Hawkins, S.M. Distinct molecular pathways in ovarian endometrioid adenocarcinoma with concurrent endometriosis. Int. J. Cancer 2018, in press.

62. Kolin, D.L.; Dinulescu, D.M.; Crum, C.P. Origin of clear cell carcinoma: Nature or nurture? J. Pathol. 2018, 244, 131-134. [CrossRef] [PubMed]

63. Klemmt, P.A.B.; Starzinski-Powitz, A. Molecular and cellular pathogenesis of endometriosis. Curr. Womens Health Rev. 2018, 14, 106-116. [CrossRef] [PubMed]

64. Liu, D.T.; Hitchcock, A. Endometriosis: Its association with retrograde menstruation, dysmenorrhoea and tubal pathology. Br. J. Obstet. Gynaecol. 1986, 93, 859-862. [CrossRef] [PubMed]

65. Liu, H.; Du, Y.; Zhang, Z.; Lv, L.; Xiong, W.; Zhang, L.; Li, N.; He, H.; Li, Q.; Liu, Y. Autophagy contributes to hypoxia-induced epithelial to mesenchymal transition of endometrial epithelial cells in endometriosis. Biol. Reprod. 2018. [CrossRef] [PubMed]

66. Allavena, G.; Carrarelli, P.; Del Bello, B.; Luisi, S.; Petraglia, F.; Maellaro, E. Autophagy is upregulated in ovarian endometriosis: A possible interplay with p53 and heme oxygenase-1. Fertil. Steril. 2015, 103, 1244-1251.e1. [CrossRef] [PubMed]

67. Liu, H.; Zhang, Z.; Xiong, W.; Zhang, L.; Xiong, Y.; Li, N.; He, H.; Du, Y.; Liu, Y. Hypoxia-inducible factor-1alpha promotes endometrial stromal cells migration and invasion by upregulating autophagy in endometriosis. Reproduction 2017, 153, 809-820. [CrossRef] [PubMed]

68. Xu, T.X.; Zhao, S.Z.; Dong, M.; Yu, X.R. Hypoxia responsive miR-210 promotes cell survival and autophagy of endometriotic cells in hypoxia. Eur. Rev. Med. Pharmacol. Sci. 2016, 20, 399-406. [PubMed]

69. Lin, X.; Dai, Y.; Xu, W.; Shi, L.; Jin, X.; Li, C.; Zhou, F.; Pan, Y.; Zhang, Y.; Lin, X.; et al. Hypoxia promotes ectopic adhesion ability of endometrial stromal cells via tgf-beta1/smad signaling in endometriosis. Endocrinology 2018, 159, 1630-1641. [CrossRef] [PubMed]

70. Yoo, J.Y.; Kim, T.H.; Fazleabas, A.T.; Palomino, W.A.; Ahn, S.H.; Tayade, C.; Schammel, D.P.; Young, S.L.; Jeong, J.W.; Lessey, B.A. Kras activation and over-expression of sirt1/bcl6 contributes to the pathogenesis of endometriosis and progesterone resistance. Sci. Rep. 2017, 7, 6765. [CrossRef] [PubMed]

71. Hsiao, K.Y.; Chang, N.; Tsai, J.L.; Lin, S.C.; Tsai, S.J.; Wu, M.H. Hypoxia-inhibited DUSP2 expression promotes IL-6/STAT3 signaling in endometriosis. Am. J. Reprod. Immunol. 2017, 78. [CrossRef] [PubMed]

72. Kim, B.G.; Yoo, J.Y.; Kim, T.H.; Shin, J.H.; Langenheim, J.F.; Ferguson, S.D.; Fazleabas, A.T.; Young, S.L.; Lessey, B.A.; Jeong, J.W. Aberrant activation of signal transducer and activator of transcription-3 (stat3) signaling in endometriosis. Hum. Reprod. (Oxf. Engl.) 2015, 30, 1069-1078. [CrossRef] [PubMed]

73. Lin, S.C.; Wang, C.C.; Wu, M.H.; Yang, S.H.; Li, Y.H.; Tsai, S.J. Hypoxia-induced microRNA-20a expression increases ERK phosphorylation and angiogenic gene expression in endometriotic stromal cells. J. Clin. Endocrinol. Metab. 2012, 97, E1515-E1523. [CrossRef] [PubMed]

74. Hsiao, K.Y.; Chang, N.; Lin, S.C.; Li, Y.H.; Wu, M.H. Inhibition of dual specificity phosphatase-2 by hypoxia promotes interleukin-8-mediated angiogenesis in endometriosis. Hum. Reprod. (Oxf. Engl.) 2014, 29, 2747-2755. [CrossRef] [PubMed]

75. Kato, M.; Yamamoto, S.; Takano, M.; Matsubara, O.; Furuya, K. Aberrant expression of the mammalian target of rapamycin, hypoxia-inducible factor-1alpha, and glucose transporter 1 in the development of ovarian clear-cell adenocarcinoma. Int. J. Gynecol. Pathol. 2012, 31, 254-263. [CrossRef] [PubMed]

76. Duska, L.R.; Garrett, L.; Henretta, M.; Ferriss, J.S.; Lee, L.; Horowitz, N. When 'never-events' occur despite adherence to clinical guidelines: The case of venous thromboembolism in clear cell cancer of the ovary compared with other epithelial histologic subtypes. Gynecol. Oncol. 2010, 116, 374-377. [CrossRef] [PubMed]

77. Hsiao, K.Y.; Lin, S.C.; Wu, M.H.; Tsai, S.J. Pathological functions of hypoxia in endometriosis. Front. Biosci. (Elite Ed.) 2015, 7, 309-321. [CrossRef] [PubMed] 
78. Zhan, L.; Wang, W.; Zhang, Y.; Song, E.; Fan, Y.; Wei, B. Hypoxia-inducible factor-1alpha: A promising therapeutic target in endometriosis. Biochimie 2016, 123, 130-137. [CrossRef] [PubMed]

79. Meserve, E.E.; Crum, C.P. Benign conditions of the ovary. In Diagnostic Gynecologic and Obstetric Pathology, 3rd ed.; Crum, C.P., Haefner, H.K., Peters, W.A., III, Eds.; Elsevier, Inc.: Philadephia, PA, USA, 2018; pp. 761-799.

80. Hantak, A.M.; Bagchi, I.C.; Bagchi, M.K. Role of uterine stromal-epithelial crosstalk in embryo implantation. Int. J. Dev. Biol. 2014, 58, 139-146. [CrossRef] [PubMed]

81. Kurita, T.; Medina, R.; Schabel, A.B.; Young, P.; Gama, P.; Parekh, T.V.; Brody, J.; Cunha, G.R.; Osteen, K.G.; Bruner-Tran, K.L.; et al. The activation function-1 domain of estrogen receptor alpha in uterine stromal cells is required for mouse but not human uterine epithelial response to estrogen. Differentiation 2005, 73, 313-322. [CrossRef] [PubMed]

82. Osteen, K.G.; Rodgers, W.H.; Gaire, M.; Hargrove, J.T.; Gorstein, F.; Matrisian, L.M. Stromal-epithelial interaction mediates steroidal regulation of metalloproteinase expression in human endometrium. Proc. Natl. Acad. Sci. USA 1994, 91, 10129-10133. [CrossRef] [PubMed]

83. Valdez, J.; Cook, C.D.; Ahrens, C.C.; Wang, A.J.; Brown, A.; Kumar, M.; Stockdale, L.; Rothenberg, D.; Renggli, K.; Gordon, E.; et al. On-demand dissolution of modular, synthetic extracellular matrix reveals local epithelial-stromal communication networks. Biomaterials 2017, 130, 90-103. [CrossRef] [PubMed]

84. Aghajanova, L.; Hamilton, A.; Kwintkiewicz, J.; Vo, K.C.; Giudice, L.C. Steroidogenic enzyme and key decidualization marker dysregulation in endometrial stromal cells from women with versus without endometriosis. Biol. Reprod. 2009, 80, 105-114. [CrossRef] [PubMed]

85. Velarde, M.C.; Aghajanova, L.; Nezhat, C.R.; Giudice, L.C. Increased mitogen-activated protein kinase kinase/extracellularly regulated kinase activity in human endometrial stromal fibroblasts of women with endometriosis reduces $3^{\prime}, 5^{\prime}$-cyclic adenosine $5^{\prime}$-monophosphate inhibition of cyclin D1. Endocrinology 2009, 150, 4701-4712. [CrossRef] [PubMed]

86. Aghajanova, L.; Horcajadas, J.A.; Weeks, J.L.; Esteban, F.J.; Nezhat, C.N.; Conti, M.; Giudice, L.C. The protein kinase a pathway-regulated transcriptome of endometrial stromal fibroblasts reveals compromised differentiation and persistent proliferative potential in endometriosis. Endocrinology 2010, 151, 1341-1355. [CrossRef] [PubMed]

87. Aghajanova, L.; Tatsumi, K.; Horcajadas, J.A.; Zamah, A.M.; Esteban, F.J.; Herndon, C.N.; Conti, M.; Giudice, L.C. Unique transcriptome, pathways, and networks in the human endometrial fibroblast response to progesterone in endometriosis. Biol. Reprod. 2011, 84, 801-815. [CrossRef] [PubMed]

88. Aghajanova, L.; Velarde, M.C.; Giudice, L.C. The progesterone receptor coactivator hic-5 is involved in the pathophysiology of endometriosis. Endocrinology 2009, 150, 3863-3870. [CrossRef] [PubMed]

89. Barragan, F.; Irwin, J.C.; Balayan, S.; Erikson, D.W.; Chen, J.C.; Houshdaran, S.; Piltonen, T.T.; Spitzer, T.L.; George, A.; Rabban, J.T.; et al. Human endometrial fibroblasts derived from mesenchymal progenitors inherit progesterone resistance and acquire an inflammatory phenotype in the endometrial niche in endometriosis. Biol. Reprod. 2016, 94, 118. [CrossRef] [PubMed]

90. Zhang, Y.; Tang, H.; Cai, J.; Zhang, T.; Guo, J.; Feng, D.; Wang, Z. Ovarian cancer-associated fibroblasts contribute to epithelial ovarian carcinoma metastasis by promoting angiogenesis, lymphangiogenesis and tumor cell invasion. Cancer Lett. 2011, 303, 47-55. [CrossRef] [PubMed]

91. Mitra, A.K.; Zillhardt, M.; Hua, Y.; Tiwari, P.; Murmann, A.E.; Peter, M.E.; Lengyel, E. MicroRNAs reprogram normal fibroblasts into cancer-associated fibroblasts in ovarian cancer. Cancer Discov. 2012, 2, 1100-1108. [CrossRef] [PubMed]

92. Hawkins, S.M.; Creighton, C.J.; Han, D.Y.; Zariff, A.; Anderson, M.L.; Gunaratne, P.H.; Matzuk, M.M. Functional microRNA involved in endometriosis. Mol. Endocrinol. 2011, 25, 821-832. [CrossRef] [PubMed]

93. Lessey, B.A.; Kim, J.J. Endometrial receptivity in the eutopic endometrium of women with endometriosis: It is affected, and let me show you why. Fertil. Steril. 2017, 108, 19-27. [CrossRef] [PubMed]

94. Capobianco, A.; Rovere-Querini, P. Endometriosis, a disease of the macrophage. Front. Immunol. 2013 , 4, 9. [CrossRef] [PubMed]

95. Bacci, M.; Capobianco, A.; Monno, A.; Cottone, L.; Di Puppo, F.; Camisa, B.; Mariani, M.; Brignole, C.; Ponzoni, M.; Ferrari, S.; et al. Macrophages are alternatively activated in patients with endometriosis and required for growth and vascularization of lesions in a mouse model of disease. Am. J. Pathol. 2009, 175, 547-556. [CrossRef] [PubMed] 
96. Canet, B.; Pons, C.; Espinosa, I.; Prat, J. Cdc42-positive macrophages may prevent malignant transformation of ovarian endometriosis. Hum. Pathol. 2012, 43, 720-725. [CrossRef] [PubMed]

97. Furuya, M.; Tanaka, R.; Miyagi, E.; Kami, D.; Nagahama, K.; Miyagi, Y.; Nagashima, Y.; Hirahara, F.; Inayama, Y.; Aoki, I. Impaired CXCL4 expression in tumor-associated macrophages (tams) of ovarian cancers arising in endometriosis. Cancer Biol. Ther. 2012, 13, 671-680. [CrossRef] [PubMed]

98. Eisermann, J.; Gast, M.J.; Pineda, J.; Odem, R.R.; Collins, J.L. Tumor necrosis factor in peritoneal fluid of women undergoing laparoscopic surgery. Fertil. Steril. 1988, 50, 573-579. [CrossRef]

99. Calhaz-Jorge, C.; Costa, A.P.; Barata, M.; Santos, M.C.; Melo, A.; Palma-Carlos, M.L. Tumour necrosis factor alpha concentrations in the peritoneal fluid of infertile women with minimal or mild endometriosis are lower in patients with red lesions only than in patients without red lesions. Hum. Reprod. (Oxf. Engl.) 2000, 15, 1256-1260. [CrossRef]

100. Jin, C.H.; Yi, K.W.; Ha, Y.R.; Shin, J.H.; Park, H.T.; Kim, T.; Hur, J.Y. Chemerin expression in the peritoneal fluid, serum, and ovarian endometrioma of women with endometriosis. Am. J. Reprod. Immunol. 2015, 74, 379-386. [CrossRef] [PubMed]

101. Young, V.J.; Brown, J.K.; Saunders, P.T.; Duncan, W.C.; Horne, A.W. The peritoneum is both a source and target of TGF-Beta in women with endometriosis. PLOS ONE 2014, 9, e106773. [CrossRef] [PubMed]

102. Worley, M.J.; Welch, W.R.; Berkowitz, R.S.; Ng, S.W. Endometriosis-associated ovarian cancer: A review of pathogenesis. Int. J. Mol. Sci. 2013, 14, 5367-5379. [CrossRef] [PubMed]

103. Lewis, C.E.; Pollard, J.W. Distinct role of macrophages in different tumor microenvironments. Cancer Res. 2006, 66, 605-612. [CrossRef] [PubMed]

104. Han, S.J.; Jung, S.Y.; Wu, S.P.; Hawkins, S.M.; Park, M.J.; Kyo, S.; Qin, J.; Lydon, J.P.; Tsai, S.Y.; Tsai, M.J.; et al. Estrogen receptor beta modulates apoptosis complexes and the inflammasome to drive the pathogenesis of endometriosis. Cell 2015, 163, 960-974. [CrossRef] [PubMed]

105. Altan, Z.M.; Denis, D.; Kagan, D.; Grund, E.M.; Palmer, S.S.; Nataraja, S.G. A long-acting tumor necrosis factor alpha-binding protein demonstrates activity in both in vitro and in vivo models of endometriosis. J. Pharmacol. Exp. Ther. 2010, 334, 460-466. [CrossRef] [PubMed]

106. Koninckx, P.R.; Craessaerts, M.; Timmerman, D.; Cornillie, F.; Kennedy, S. Anti-TNF-alpha treatment for deep endometriosis-associated pain: A randomized placebo-controlled trial. Hum. Reprod. (Oxf. Engl.) 2008, 23, 2017-2023. [CrossRef] [PubMed]

107. Wei, J.J.; William, J.; Bulun, S. Endometriosis and ovarian cancer: A review of clinical, pathologic, and molecular aspects. Int. J. Gynecol. Pathol. 2011, 30, 553-568. [CrossRef] [PubMed]

108. Yamaguchi, K.; Mandai, M.; Toyokuni, S.; Hamanishi, J.; Higuchi, T.; Takakura, K.; Fujii, S. Contents of endometriotic cysts, especially the high concentration of free iron, are a possible cause of carcinogenesis in the cysts through the iron-induced persistent oxidative stress. Clin. Cancer Res. 2008, 14, 32-40. [CrossRef] [PubMed]

109. Mandai, M.; Matsumura, N.; Baba, T.; Yamaguchi, K.; Hamanishi, J.; Konishi, I. Ovarian clear cell carcinoma as a stress-responsive cancer: Influence of the microenvironment on the carcinogenesis and cancer phenotype. Cancer Lett. 2011, 310, 129-133. [CrossRef] [PubMed]

110. Shigetomi, H.; Higashiura, Y.; Kajihara, H.; Kobayashi, H. A potential link of oxidative stress and cell cycle regulation for development of endometriosis. Gynecol. Endocrinol. 2012, 28, 897-902. [CrossRef] [PubMed]

111. Vercellini, P.; Crosignani, P.; Somigliana, E.; Vigano, P.; Buggio, L.; Bolis, G.; Fedele, L. The 'incessant menstruation' hypothesis: A mechanistic ovarian cancer model with implications for prevention. Hum. Reprod. (Oxf. Engl.) 2011, 26, 2262-2273. [CrossRef] [PubMed]

112. Young, V.J.; Brown, J.K.; Maybin, J.; Saunders, P.T.; Duncan, W.C.; Horne, A.W. Transforming growth factor- $\beta$ induced warburg-like metabolic reprogramming may underpin the development of peritoneal endometriosis. J. Clin. Endocrinol. Metab. 2014, 99, 3450-3459. [CrossRef] [PubMed]

113. Young, V.J.; Ahmad, S.F.; Brown, J.K.; Duncan, W.C.; Horne, A.W. Id2 mediates the transforming growth factor- $\beta 1$-induced warburg-like effect seen in the peritoneum of women with endometriosis. MHR Basic Sci. Reprod. Med. 2016, 22, 648-654. [CrossRef] [PubMed]

114. Dominguez, F.; Ferrando, M.; Diaz-Gimeno, P.; Quintana, F.; Fernandez, G.; Castells, I.; Simon, C. Lipidomic profiling of endometrial fluid in women with ovarian endometriosisdagger. Biol. Reprod. 2017, 96, 772-779. [CrossRef] [PubMed] 
115. Li, J.; Gao, Y.; Guan, L.; Zhang, H.; Sun, J.; Gong, X.; Li, D.; Chen, P.; Ma, Z.; Liang, X.; et al. Discovery of phosphatidic acid, phosphatidylcholine, and phosphatidylserine as biomarkers for early diagnosis of endometriosis. Front. Physiol 2018, 9, 14. [CrossRef] [PubMed]

116. Cheng, Y.H.; Imir, A.; Fenkci, V.; Yilmaz, M.B.; Bulun, S.E. Stromal cells of endometriosis fail to produce paracrine factors that induce epithelial 17beta-hydroxysteroid dehydrogenase type 2 gene and its transcriptional regulator sp1: A mechanism for defective estradiol metabolism. Am. J. Obstet. Gynecol. 2007, 196, 391.e1-391.e7; discussion 391.e7-391.e8. [CrossRef] [PubMed]

117. Khorram, O.; Taylor, R.N.; Ryan, I.P.; Schall, T.J.; Landers, D.V. Peritoneal fluid concentrations of the cytokine rantes correlate with the severity of endometriosis. Am. J. Obstet. Gynecol. 1993, 169, 1545-1549. [CrossRef]

118. Tsai, S.J.; Wu, M.H.; Lin, C.C.; Sun, H.S.; Chen, H.M. Regulation of steroidogenic acute regulatory protein expression and progesterone production in endometriotic stromal cells. J. Clin. Endocrinol. Metab. 2001, 86, 5765-5773. [CrossRef] [PubMed]

119. Arosh, J.A.; Lee, J.; Balasubbramanian, D.; Stanley, J.A.; Long, C.R.; Meagher, M.W.; Osteen, K.G.; Bruner-Tran, K.L.; Burghardt, R.C.; Starzinski-Powitz, A.; et al. Molecular and preclinical basis to inhibit PGE2 receptors EP2 and EP4 as a novel nonsteroidal therapy for endometriosis. Proc. Natl. Acad. Sci. USA 2015, 112, 9716-9721. [CrossRef] [PubMed]

120. Modugno, F.; Ness, R.B.; Allen, G.O.; Schildkraut, J.M.; Davis, F.G.; Goodman, M.T. Oral contraceptive use, reproductive history, and risk of epithelial ovarian cancer in women with and without endometriosis. Am. J. Obstet. Gynecol. 2004, 191, 733-740. [CrossRef] [PubMed]

121. Hawkins, S.M.; Buchold, G.M.; Matzuk, M.M. Minireview: The roles of small rna pathways in reproductive medicine. Mol. Endocrinol. 2011, 25, 1257-1279. [CrossRef] [PubMed]

122. Bartel, D.P. MicroRNAs: Genomics, biogenesis, mechanism, and function. Cell 2004, 116, 281-297. [CrossRef]

123. Bartel, D.P.; Chen, C.Z. Micromanagers of gene expression: The potentially widespread influence of metazoan microRNAs. Nat. Rev. 2004, 5, 396-400. [CrossRef] [PubMed]

124. Yanaihara, N.; Noguchi, Y.; Saito, M.; Takenaka, M.; Takakura, S.; Yamada, K.; Okamoto, A. microRNA gene expression signature driven by miR-9 overexpression in ovarian clear cell carcinoma. PLoS ONE 2016, 11, e0162584. [CrossRef] [PubMed]

125. Zhang, X.; Guo, G.; Wang, G.; Zhao, J.; Wang, B.; Yu, X.; Ding, Y. Profile of differentially expressed miRNAs in high-grade serous carcinoma and clear cell ovarian carcinoma, and the expression of miR-510 in ovarian carcinoma. Mol. Med. Rep. 2015, 12, 8021-8031. [CrossRef] [PubMed]

126. Vilming Elgaaen, B.; Olstad, O.K.; Haug, K.B.; Brusletto, B.; Sandvik, L.; Staff, A.C.; Gautvik, K.M.; Davidson, B. Global miRNA expression analysis of serous and clear cell ovarian carcinomas identifies differentially expressed miRNAs including miR-200c-3p as a prognostic marker. BMC Cancer 2014, 14, 80. [CrossRef] [PubMed]

127. Wyman, S.K.; Parkin, R.K.; Mitchell, P.S.; Fritz, B.R.; O’Briant, K.; Godwin, A.K.; Urban, N.; Drescher, C.W.; Knudsen, B.S.; Tewari, M. Repertoire of microRNAs in epithelial ovarian cancer as determined by next generation sequencing of small RNA cDNA libraries. PLoS ONE 2009, 4, e5311. [CrossRef] [PubMed]

128. Wu, R.L.; Ali, S.; Bandyopadhyay, S.; Alosh, B.; Hayek, K.; Daaboul, M.F.; Winer, I.; Sarkar, F.H.; Ali-Fehmi, R. Comparative analysis of differentially expressed miRNAs and their downstream mRNAs in ovarian cancer and its associated endometriosis. J Cancer Sci. Ther. 2015, 7, 258-265. [PubMed]

129. Iorio, M.V.; Visone, R.; Di Leva, G.; Donati, V.; Petrocca, F.; Casalini, P.; Taccioli, C.; Volinia, S.; Liu, C.G.; Alder, H.; et al. microRNA signatures in human ovarian cancer. Cancer Res. 2007, 67, 8699-8707. [CrossRef] [PubMed]

130. Braicu, O.L.; Budisan, L.; Buiga, R.; Jurj, A.; Achimas-Cadariu, P.; Pop, L.A.; Braicu, C.; Irimie, A.; Berindan-Neagoe, I. miRNA expression profiling in formalin-fixed paraffin-embedded endometriosis and ovarian cancer samples. Onco Targets Ther. 2017, 10, 4225-4238. [CrossRef] [PubMed]

131. Zhao, H.; Ding, Y.; Tie, B.; Sun, Z.F.; Jiang, J.Y.; Zhao, J.; Lin, X.; Cui, S. miRNA expression pattern associated with prognosis in elderly patients with advanced OPSC and OCC. Int. J. Oncol. 2013, 43, 839-849. [CrossRef] [PubMed]

132. Calura, E.; Fruscio, R.; Paracchini, L.; Bignotti, E.; Ravaggi, A.; Martini, P.; Sales, G.; Beltrame, L.; Clivio, L.; Ceppi, L.; et al. miRNA landscape in stage i epithelial ovarian cancer defines the histotype specificities. Clin. Cancer Res. 2013, 19, 4114-4123. [CrossRef] [PubMed] 
133. Suryawanshi, S.; Vlad, A.M.; Lin, H.M.; Mantia-Smaldone, G.; Laskey, R.; Lee, M.; Lin, Y.; Donnellan, N.; Klein-Patel, M.; Lee, T.; et al. Plasma microRNAs as novel biomarkers for endometriosis and endometriosisassociated ovarian cancer. Clin. Cancer Res. 2013, 19, 1213-1224. [CrossRef] [PubMed]

134. Liu, S.; Gao, S.; Wang, X.Y.; Wang, D.B. Expression of miR-126 and Crk in endometriosis: miR-126 may affect the progression of endometriosis by regulating Crk expression. Arch. Gynecol. Obstet. 2012, 285, 1065-1072. [CrossRef] [PubMed]

135. Ebrahimi, F.; Gopalan, V.; Smith, R.A.; Lam, A.K. miR-126 in human cancers: Clinical roles and current perspectives. Exp. Mol. Pathol. 2014, 96, 98-107. [CrossRef] [PubMed]

136. Sestito, R.; Cianfrocca, R.; Rosano, L.; Tocci, P.; Semprucci, E.; Di Castro, V.; Caprara, V.; Ferrandina, G.; Sacconi, A.; Blandino, G.; et al. miR-30a inhibits endothelin a receptor and chemoresistance in ovarian carcinoma. Oncotarget 2016, 7, 4009-4023. [CrossRef] [PubMed]

137. Bai, L.; Wang, H.; Wang, A.H.; Zhang, L.Y.; Bai, J. microRNA-532 and microRNA-3064 inhibit cell proliferation and invasion by acting as direct regulators of human telomerase reverse transcriptase in ovarian cancer. PLoS ONE 2017, 12, e0173912. [CrossRef] [PubMed]

138. Humphries, B.; Yang, C. The microRNA-200 family: Small molecules with novel roles in cancer development, progression and therapy. Oncotarget 2015, 6, 6472-6498. [CrossRef] [PubMed]

139. Greaves, E.; Critchley, H.O.D.; Horne, A.W.; Saunders, P.T.K. Relevant human tissue resources and laboratory models for use in endometriosis research. Acta. Obstet. Gynecol. Scand. 2017, 96, 644-658. [CrossRef] [PubMed]

140. King, C.M.; Barbara, C.; Prentice, A.; Brenton, J.D.; Charnock-Jones, D.S. Models of endometriosis and their utility in studying progression to ovarian clear cell carcinoma. J. Pathol. 2016, 238, 185-196. [CrossRef] [PubMed]

141. Cancer Genome Atlas Research Network. Integrated genomic analyses of ovarian carcinoma. Nature 2011, 474, 609-615. [CrossRef] [PubMed]

142. Hardy, S.; Kitamura, M.; HarrisStansil, T.; Dai, Y.M.; Phipps, M.L. Construction of adenovirus vectors through Cre-lox recombination. J. Virol. 1997, 71, 1842-1849. [PubMed]

143. Mullany, L.K.; Fan, H.Y.; Liu, Z.; White, L.D.; Marshall, A.; Gunaratne, P.; Anderson, M.L.; Creighton, C.J.; Xin, L.; Deavers, M.; et al. Molecular and functional characteristics of ovarian surface epithelial cells transformed by KrasG12D and loss of Pten in a mouse model in vivo. Oncogene 2011, 30, 3522-3536. [CrossRef] [PubMed]

144. Jamin, S.P.; Arango, N.A.; Mishina, Y.; Hanks, M.C.; Behringer, R.R. Requirement of bmpr1a for mullerian duct regression during male sexual development. Nat. Genet. 2002, 32, 408-410. [CrossRef] [PubMed]

145. Fan, H.Y.; Shimada, M.; Liu, Z.; Cahill, N.; Noma, N.; Wu, Y.; Gossen, J.; Richards, J.S. Selective expression of KrasG12D in granulosa cells of the mouse ovary causes defects in follicle development and ovulation. Development 2008, 135, 2127-2137. [CrossRef] [PubMed]

146. Wu, R.; Zhai, Y.; Kuick, R.; Karnezis, A.N.; Garcia, P.; Naseem, A.; Hu, T.C.; Fearon, E.R.; Cho, K.R. Impact of oviductal versus ovarian epithelial cell of origin on ovarian endometrioid carcinoma phenotype in the mouse. J. Pathol. 2016, 240, 341-351. [CrossRef] [PubMed]

147. Russo, A.; Czarnecki, A.A.; Dean, M.; Modi, D.A.; Lantvit, D.D.; Hardy, L.; Baligod, S.; Davis, D.A.; Wei, J.J.; Burdette, J.E. Pten loss in the fallopian tube induces hyperplasia and ovarian tumor formation. Oncogene 2018, 37, 1976-1990. [CrossRef] [PubMed]

148. Soyal, S.M.; Mukherjee, A.; Lee, K.Y.S.; Li, J.; Li, H.; DeMayo, F.J.; Lydon, J.P. Cre-mediated recombination in cell lineages that express the progesterone receptor. Genesis 2005, 41, 58-66. [CrossRef] [PubMed]

149. Wu, R.; Zhai, Y.; Fearon, E.R.; Cho, K.R. Diverse mechanisms of beta-catenin deregulation in ovarian endometrioid adenocarcinomas. Cancer Res. 2001, 61, 8247-8255. [PubMed]

150. Saegusa, M.; Okayasu, I. Frequent nuclear beta-catenin accumulation and associated mutations in endometrioid-type endometrial and ovarian carcinomas with squamous differentiation. J. Pathol. 2001, 194, 59-67. [CrossRef] [PubMed]

151. Palacios, J.; Gamallo, C. Mutations in the beta-catenin gene (CTNNB1) in endometrioid ovarian carcinomas. Cancer Res. 1998, 58, 1344-1347. [PubMed]

152. Gamallo, C.; Palacios, J.; Moreno, G.; Calvo de Mora, J.; Suarez, A.; Armas, A. Beta-catenin expression pattern in stage I and II ovarian carcinomas: Relationship with beta-catenin gene mutations, clinicopathological features, and clinical outcome. Am. J. Pathol. 1999, 155, 527-536. [CrossRef] 
153. Wright, K.; Wilson, P.; Morland, S.; Campbell, I.; Walsh, M.; Hurst, T.; Ward, B.; Cummings, M.; Chenevix-Trench, G. Beta-catenin mutation and expression analysis in ovarian cancer: Exon 3 mutations and nuclear translocation in 16\% of endometrioid tumours. Int. J. Cancer 1999, 82, 625-629. [CrossRef]

154. Dharmaraj, N.; Chapela, P.J.; Morgado, M.; Hawkins, S.M.; Lessey, B.A.; Young, S.L.; Carson, D.D. Expression of the transmembrane mucins, MUC1, MUC4 and MUC16, in normal endometrium and in endometriosis. Hum. Reprod. (Oxf. Engl.) 2014, 29, 1730-1738. [CrossRef] [PubMed]

155. Campbell, I.G.; Russell, S.E.; Choong, D.Y.; Montgomery, K.G.; Ciavarella, M.L.; Hooi, C.S.; Cristiano, B.E.; Pearson, R.B.; Phillips, W.A. Mutation of the PIK3CA gene in ovarian and breast cancer. Cancer Res. 2004, 64, 7678-7681. [CrossRef] [PubMed]

156. Kurman, R.J.; Shih, I.-M. Molecular pathogenesis and extraovarian origin of epithelial ovarian cancer-Shifting the paradigm. Hum. Pathol. 2011, 42, 918-931. [CrossRef] [PubMed]

157. Chandler, R.L.; Damrauer, J.S.; Raab, J.R.; Schisler, J.C.; Wilkerson, M.D.; Didion, J.P.; Starmer, J.; Serber, D.; Yee, D.; Xiong, J. Coexistent ARID1A-PIK3CA mutations promote ovarian clear-cell tumorigenesis through pro-tumorigenic inflammatory cytokine signalling. Nat. Commun. 2015, 6, 6118. [CrossRef] [PubMed]

158. Guan, B.; Rahmanto, Y.S.; Wu, R.C.; Wang, Y.; Wang, Z.; Wang, T.L.; Shih Ie, M. Roles of deletion of ARID1A, a tumor suppressor, in mouse ovarian tumorigenesis. J. Natl. Cancer Inst. 2014, 106. [CrossRef] [PubMed]

159. Wang, X.; Khatri, S.; Broaddus, R.; Wang, Z.; Hawkins, S.M. Deletion of ARID1A in reproductive tract mesenchymal cells reduces fertility in female mice. Biol. Reprod. 2016, 94, 93. [CrossRef] [PubMed]

160. Kim, T.H.; Yoo, J.Y.; Wang, Z.; Lydon, J.P.; Khatri, S.; Hawkins, S.M.; Leach, R.E.; Fazleabas, A.T.; Young, S.L.; Lessey, B.A.; et al. Arid1a is essential for endometrial function during early pregnancy. PLoS Genet. 2015, 11, e1005537. [CrossRef] [PubMed]

161. Wu, R.; Hendrix-Lucas, N.; Kuick, R.; Zhai, Y.; Schwartz, D.R.; Akyol, A.; Hanash, S.; Misek, D.E.; Katabuchi, H.; Williams, B.O.; et al. Mouse model of human ovarian endometrioid adenocarcinoma based on somatic defects in the Wnt/beta-catenin and PI3K/Pten signaling pathways. Cancer Cell 2007, 11, 321-333. [CrossRef] [PubMed]

162. Dinulescu, D.M.; Ince, T.A.; Quade, B.J.; Shafer, S.A.; Crowley, D.; Jacks, T. Role of K-ras and Pten in the development of mouse models of endometriosis and endometrioid ovarian cancer. Nat. Med. 2005, 11, 63-70. [CrossRef] [PubMed]

163. Fan, H.-Y.; Liu, Z.; Paquet, M.; Wang, J.; Lydon, J.P.; DeMayo, F.J.; Richards, J.S. Cell type-specific targeted mutations of Kras and Pten document proliferation arrest in granulosa cells versus oncogenic insult to ovarian surface epithelial cells. Cancer Res. 2009, 69, 6463-6472. [CrossRef] [PubMed]

164. Lague, M.N.; Paquet, M.; Fan, H.Y.; Kaartinen, M.J.; Chu, S.; Jamin, S.P.; Behringer, R.R.; Fuller, P.J.; Mitchell, A.; Dore, M.; et al. Synergistic effects of Pten loss and Wnt/CTNNB1 signaling pathway activation in ovarian granulosa cell tumor development and progression. Carcinogenesis 2008, 29, 2062-2072. [CrossRef] [PubMed]

165. Tanwar, P.S.; Zhang, L.; Kaneko-Tarui, T.; Curley, M.D.; Taketo, M.M.; Rani, P.; Roberts, D.J.; Teixeira, J.M. Mammalian target of rapamycin is a therapeutic target for murine ovarian endometrioid adenocarcinomas with dysregulated Wnt/ $\beta$-catenin and Pten. PLoS ONE 2011, 6, e20715. [CrossRef] [PubMed]

166. Van der Horst, P.H.; van der Zee, M.; Heijmans-Antonissen, C.; Jia, Y.; DeMayo, F.J.; Lydon, J.P.; van Deurzen, C.H.; Ewing, P.C.; Burger, C.W.; Blok, L.J. A mouse model for endometrioid ovarian cancer arising from the distal oviduct. Int. J. Cancer 2014, 135, 1028-1037. [CrossRef] [PubMed]

167. Wu, R.; Baker, S.J.; Hu, T.C.; Norman, K.M.; Fearon, E.R.; Cho, K.R. Type I to type II ovarian carcinoma progression: Mutant Trp53 or PIK3CA confers a more aggressive tumor phenotype in a mouse model of ovarian cancer. Am. J. Pathol. 2013, 182, 1391-1399. [CrossRef] [PubMed]

168. Budiu, R.A.; Diaconu, I.; Chrissluis, R.; Dricu, A.; Edwards, R.P.; Vlad, A.M. A conditional mouse model for human muc1-positive endometriosis shows the presence of anti-muc1 antibodies and foxp3+ regulatory $t$ cells. Dis. Model Mech. 2009, 2, 593-603. [CrossRef] [PubMed]

169. Cousins, F.L.; Murray, A.; Esnal, A.; Gibson, D.A.; Critchley, H.O.; Saunders, P.T. Evidence from a mouse model that epithelial cell migration and mesenchymal-epithelial transition contribute to rapid restoration of uterine tissue integrity during menstruation. PLoS ONE 2014, 9, e86378. [CrossRef] [PubMed]

170. Brasted, M.; White, C.A.; Kennedy, T.G.; Salamonsen, L.A. Mimicking the events of menstruation in the murine uterus. Biol. Reprod. 2003, 69, 1273-1280. [CrossRef] [PubMed] 
171. Cheng, C.W.; Bielby, H.; Licence, D.; Smith, S.K.; Print, C.G.; Charnock-Jones, D.S. Quantitative cellular and molecular analysis of the effect of progesterone withdrawal in a murine model of decidualization. Biol. Reprod. 2007, 76, 871-883. [CrossRef] [PubMed]

172. Cheng, C.W.; Licence, D.; Cook, E.; Luo, F.; Arends, M.J.; Smith, S.K.; Print, C.G.; Charnock-Jones, D.S. Activation of mutated K-ras in donor endometrial epithelium and stroma promotes lesion growth in an intact immunocompetent murine model of endometriosis. J. Pathol. 2011, 224, 261-269. [CrossRef] [PubMed]

173. Greaves, E.; Cousins, F.L.; Murray, A.; Esnal-Zufiaurre, A.; Fassbender, A.; Horne, A.W.; Saunders, P.T. A novel mouse model of endometriosis mimics human phenotype and reveals insights into the inflammatory contribution of shed endometrium. Am. J. Pathol. 2014, 184, 1930-1939. [CrossRef] [PubMed]

174. Chandler, R.L.; Raab, J.R.; Vernon, M.; Magnuson, T.; Schisler, J.C. Global gene expression profiling of a mouse model of ovarian clear cell carcinoma caused by ARID1A and PIK3CA mutations implicates a role for inflammatory cytokine signaling. Genom. Data 2015, 5, 329-332. [CrossRef] [PubMed]

175. Harada, N.; Tamai, Y.; Ishikawa, T.; Sauer, B.; Takaku, K.; Oshima, M.; Taketo, M.M. Intestinal polyposis in mice with a dominant stable mutation of the beta-catenin gene. EMBO J. 1999, 18, 5931-5942. [CrossRef] [PubMed]

176. Uehara, S.; Abe, H.; Hoshiai, H.; Yajima, A.; Suzuki, M. Establishment and characterization of ovarian endometrioid carcinoma cell line. Gynecol. Oncol. 1984, 17, 314-325. [CrossRef]

177. Gorai, I.; Nakazawa, T.; Miyagi, E.; Hirahara, F.; Nagashima, Y.; Minaguchi, H. Establishment and characterization of two human ovarian clear cell adenocarcinoma lines from metastatic lesions with different properties. Gynecol. Oncol. 1995, 57, 33-46. [CrossRef] [PubMed]

178. Domcke, S.; Sinha, R.; Levine, D.A.; Sander, C.; Schultz, N. Evaluating cell lines as tumour models by comparison of genomic profiles. Nat. Commun. 2013, 4, 2126. [CrossRef] [PubMed]

179. Anglesio, M.S.; Wiegand, K.C.; Melnyk, N.; Chow, C.; Salamanca, C.; Prentice, L.M.; Senz, J.; Yang, W.; Spillman, M.A.; Cochrane, D.R.; et al. Type-specific cell line models for type-specific ovarian cancer research. PLoS ONE 2013, 8, e72162. [CrossRef]

180. Beaufort, C.M.; Helmijr, J.C.; Piskorz, A.M.; Hoogstraat, M.; Ruigrok-Ritstier, K.; Besselink, N.; Murtaza, M.; van, I.W.F.; Heine, A.A.; Smid, M.; et al. Ovarian cancer cell line panel (OCCP): Clinical importance of in vitro morphological subtypes. PLoS ONE 2014, 9, e103988. [CrossRef] [PubMed]

181. Ince, T.A.; Sousa, A.D.; Jones, M.A.; Harrell, J.C.; Agoston, E.S.; Krohn, M.; Selfors, L.M.; Liu, W.; Chen, K.; Yong, M.; et al. Characterization of twenty-five ovarian tumour cell lines that phenocopy primary tumours. Nat. Commun. 2015, 6, 7419. [CrossRef] [PubMed]

182. Blayney, J.K.; Davison, T.; McCabe, N.; Walker, S.; Keating, K.; Delaney, T.; Greenan, C.; Williams, A.R.; McCluggage, W.G.; Capes-Davis, A.; et al. Prior knowledge transfer across transcriptional data sets and technologies using compositional statistics yields new mislabelled ovarian cell line. Nucleic Acids Res. 2016, 44, e137. [CrossRef] [PubMed]

183. Zeitvogel, A.; Baumann, R.; Starzinski-Powitz, A. Identification of an invasive, n-cadherin-expressing epithelial cell type in endometriosis using a new cell culture model. Am. J. Pathol. 2001, 159, 1839-1852. [CrossRef]

184. Brueggmann, D.; Templeman, C.; Starzinski-Powitz, A.; Rao, N.P.; Gayther, S.A.; Lawrenson, K. Novel threedimensional in vitro models of ovarian endometriosis. J. Ovarian Res. 2014, 7, 17. [CrossRef] [PubMed]

185. Bono, Y.; Kyo, S.; Takakura, M.; Maida, Y.; Mizumoto, Y.; Nakamura, M.; Nomura, K.; Kiyono, T.; Inoue, M. Creation of immortalised epithelial cells from ovarian endometrioma. Br. J. Cancer 2012, 106, 1205-1213. [CrossRef] [PubMed]

186. Ohta, I.; Gorai, I.; Miyamoto, Y.; Yang, J.; Zheng, J.H.; Kawata, N.; Hirahara, F.; Shirotake, S. Cyclophosphamide and 5-fluorouracil act synergistically in ovarian clear cell adenocarcinoma cells. Cancer Lett. 2001, 162, 39-48. [CrossRef]

187. Provencher, D.M.; Lounis, H.; Champoux, L.; Tetrault, M.; Manderson, E.N.; Wang, J.C.; Eydoux, P.; Savoie, R.; Tonin, P.N.; Mes-Masson, A.M. Characterization of four novel epithelial ovarian cancer cell lines. In Vitro Cell Dev. Biol. Anim. 2000, 36, 357-361. [CrossRef]

188. Nozawa, S.; Tsukazaki, K.; Sakayori, M.; Jeng, C.H.; Iizuka, R. Establishment of a human ovarian clear cell carcinoma cell line (RMG-I) and its single cell cloning-with special reference to the stem cell of the tumor. Hum. Cell 1988, 1, 426-435. [PubMed] 
189. Wong, W.S.; Wong, Y.F.; Ng, Y.T.; Huang, P.D.; Chew, E.C.; Ho, T.H.; Chang, M.Z. Establishment and characterization of a new human cell line derived from ovarian clear cell carcinoma. Gynecol. Oncol. 1990, 38, 37-45. [CrossRef]

190. Yamada, K.; Tachibana, T.; Hashimoto, H.; Suzuki, K.; Yanagida, S.; Endoh, H.; Kimura, E.; Yasuda, M.; Tanaka, T.; Ishikawa, H. Establishment and characterization of cell lines derived from serous adenocarcinoma (JHOS-2) and clear cell adenocarcinoma (JHOC-5, JHOC-6) of human ovary. Hum. Cell 1999, 12, 131-138. [PubMed]

191. Lau, D.H.; Lewis, A.D.; Ehsan, M.N.; Sikic, B.I. Multifactorial mechanisms associated with broad cross-resistance of ovarian carcinoma cells selected by cyanomorpholino doxorubicin. Cancer Res. 1991, 51, 5181-5187. [PubMed]

192. Yanagibashi, T.; Gorai, I.; Nakazawa, T.; Miyagi, E.; Hirahara, F.; Kitamura, H.; Minaguchi, H. Complexity of expression of the intermediate filaments of six new human ovarian carcinoma cell lines: New expression of cytokeratin 20. Br. J. Cancer 1997, 76, 829-835. [CrossRef] [PubMed]

193. Stordal, B.; Timms, K.; Farrelly, A.; Gallagher, D.; Busschots, S.; Renaud, M.; Thery, J.; Williams, D.; Potter, J.; Tran, T.; et al. Brca1/2 mutation analysis in 41 ovarian cell lines reveals only one functionally deleterious brca1 mutation. Mol. Oncol. 2013, 7, 567-579. [CrossRef] [PubMed]

194. Benard, J.; Da Silva, J.; De Blois, M.C.; Boyer, P.; Duvillard, P.; Chiric, E.; Riou, G. Characterization of a human ovarian adenocarcinoma line, IGROV1, in tissue culture and in nude mice. Cancer Res. 1985, 45, 4970-4979. [PubMed]

195. Hills, C.A.; Kelland, L.R.; Abel, G.; Siracky, J.; Wilson, A.P.; Harrap, K.R. Biological properties of ten human ovarian carcinoma cell lines: Calibration in vitro against four platinum complexes. Br. J. Cancer 1989, 59, 527-534. [CrossRef] [PubMed]

196. Van den Berg-Bakker, C.A.; Hagemeijer, A.; Franken-Postma, E.M.; Smit, V.T.; Kuppen, P.J.; van Ravenswaay Claasen, H.H.; Cornelisse, C.J.; Schrier, P.I. Establishment and characterization of 7 ovarian carcinoma cell lines and one granulosa tumor cell line: Growth features and cytogenetics. Int. J. Cancer 1993, 53, 613-620. [CrossRef] [PubMed]

197. Eva, A.; Robbins, K.C.; Andersen, P.R.; Srinivasan, A.; Tronick, S.R.; Reddy, E.P.; Ellmore, N.W.; Galen, A.T.; Lautenberger, J.A.; Papas, T.S.; et al. Cellular genes analogous to retroviral onc genes are transcribed in human tumour cells. Nature 1982, 295, 116-119. [CrossRef] [PubMed]

198. Buick, R.N.; Pullano, R.; Trent, J.M. Comparative properties of five human ovarian adenocarcinoma cell lines. Cancer Res. 1985, 45, 3668-3676. [PubMed]

199. Fogh, J. MSKCC. Available online: http:/ / www.mskcc.org (accessed on 14 June 2018).

200. Han, S.J.; Hawkins, S.M.; Begum, K.; Jung, S.Y.; Kovanci, E.; Qin, J.; Lydon, J.P.; DeMayo, F.J.; O’Malley, B.W. A new isoform of steroid receptor coactivator-1 is crucial for pathogenic progression of endometriosis. Nat. Med. 2012, 18, 1102-1111. [CrossRef] [PubMed]

201. Komiyama, S.; Aoki, D.; Katsuki, Y.; Nozawa, S. Proliferative activity of early ovarian clear cell adenocarcinoma depends on association with endometriosis. Eur. J. Obstet. Gynecol. Reprod. Biol. 2006, 127, 130-136. [CrossRef] [PubMed]

202. Lee, J.M.; Mhawech-Fauceglia, P.; Lee, N.; Parsanian, L.C.; Lin, Y.G.; Gayther, S.A.; Lawrenson, K. A three-dimensional microenvironment alters protein expression and chemosensitivity of epithelial ovarian cancer cells in vitro. Lab. Investig. 2013, 93, 528-542. [PubMed]

203. Lal-Nag, M.; McGee, L.; Guha, R.; Lengyel, E.; Kenny, H.A.; Ferrer, M. A high-throughput screening model of the tumor microenvironment for ovarian cancer cell growth. SLAS Discov. 2017, 22, 494-506. [CrossRef] [PubMed]

204. Chowanadisai, W.; Messerli, S.M.; Miller, D.H.; Medina, J.E.; Hamilton, J.W.; Messerli, M.A.; Brodsky, A.S. Cisplatin resistant spheroids model clinically relevant survival mechanisms in ovarian tumors. PLoS ONE 2016, 11, e0151089. [CrossRef] [PubMed]

205. Tanenbaum, L.M.; Mantzavinou, A.; Subramanyam, K.S.; Del Carmen, M.G.; Cima, M.J. Ovarian cancer spheroid shrinkage following continuous exposure to cisplatin is a function of spheroid diameter. Gynecol. Oncol. 2017, 146, 161-169. [CrossRef] [PubMed]

206. Arnold, J.T.; Kaufman, D.G.; Seppala, M.; Lessey, B.A. Endometrial stromal cells regulate epithelial cell growth in vitro: A new co-culture model. Hum. Reprod. (Oxf. Engl.) 2001, 16, 836-845. [CrossRef] 
207. Mori, M.; Ito, F.; Shi, L.; Wang, Y.; Ishida, C.; Hattori, Y.; Niwa, M.; Hirayama, T.; Nagasawa, H.; Iwase, A.; et al. Ovarian endometriosis-associated stromal cells reveal persistently high affinity for iron. Redox Biol. 2015, 6, 578-586. [CrossRef] [PubMed]

208. Chan, R.W.S.; Lee, C.L.; Ng, E.H.Y.; Yeung, W.S.B. Co-culture with macrophages enhances the clonogenic and invasion activity of endometriotic stromal cells. Cell Prolif. 2017, 50. [CrossRef] [PubMed]

209. Turco, M.Y.; Gardner, L.; Hughes, J.; Cindrova-Davies, T.; Gomez, M.J.; Farrell, L.; Hollinshead, M.; Marsh, S.G.E.; Brosens, J.J.; Critchley, H.O.; et al. Long-term, hormone-responsive organoid cultures of human endometrium in a chemically defined medium. Nat. Cell Biol. 2017, 19, 568-577. [CrossRef] [PubMed]

210. Boretto, M.; Cox, B.; Noben, M.; Hendriks, N.; Fassbender, A.; Roose, H.; Amant, F.; Timmerman, D.; Tomassetti, C.; Vanhie, A.; et al. Development of organoids from mouse and human endometrium showing endometrial epithelium physiology and long-term expandability. Development 2017, 144, 1775-1786. [CrossRef] [PubMed]

211. Practice bulletin No. 114: Management of endometriosis. Obstet. Gynecol. 2010, 116, 223-236.

212. Shakiba, K.; Bena, J.F.; McGill, K.M.; Minger, J.; Falcone, T. Surgical treatment of endometriosis: A 7-year follow-up on the requirement for further surgery. Obstet. Gynecol. 2008, 111, 1285-1292. [CrossRef] [PubMed]

213. Yeung, T.L.; Sheng, J.; Leung, C.S.; Li, F.; Kim, J.; Ho, S.Y.; Matzuk, M.M.; Lu, K.H.; Wong, S.T.C.; Mok, S.C. Systematic identification of druggable epithelial-stromal crosstalk signaling networks in ovarian cancer. J. Natl. Cancer Inst. 2018. [CrossRef] [PubMed]

(C) 2018 by the authors. Licensee MDPI, Basel, Switzerland. This article is an open access article distributed under the terms and conditions of the Creative Commons Attribution (CC BY) license (http://creativecommons.org/licenses/by/4.0/). 